\title{
THE ROLE OF FERTILIZATION PRACTICES IN THE YIELD AND QUALITY OF CARROT (Daucus carota $\mathbf{L}$.
}

Selostus: Lannoitusmenetelmien vaikutus porkkanan satoon ja sisäiseen laatuun

\section{AINO-MAIJA EVERS}

Kemira Oy, Espoo Research Centre Luoteisrinne 2, 02270 Espoo, Finland

ACademic Dissertation

TO BE PRESENTED, WITH THE PERMISSION OF THE

FACULTY OF Agriculture and Forestry OF THE

UNIVERSITY OF HELSINKI, FOR PUBLIC CRITICISM

in Auditorium 12, Unioninkatu 34, Helsinki,

ON NOVEMBER 17th 1989, AT 12 O'CLOCK NOON

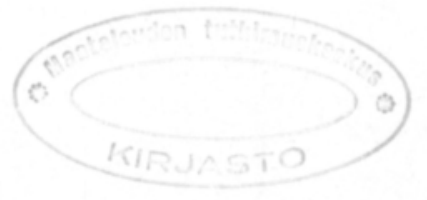





\section{Preface}

This research was carried out at Kemira Oy's Espoo Research Centre during 1985-1989. I am deeply grateful to my teacher and supervisor, Professor Erkki Kaukovirta, Head of the Department of Horticulture, University of Helsinki, for his support and most valuable instructions and advice during every stage of this study.

I am most grateful to Professor Eero Varis and Professor Antti Jaakkola for reading the manuscript and for their useful suggestions. I wish to express my warmest gratitude to Professor Anna-Liisa Varis for her kind support and guidance. I owe my deepest gratitude to Dr. Heikki Rosenqvist, Head to the Espoo Research Centre, and to Kemira Oy for providing excellent working facilities.

The encouraging attitude of Dr. Ari Lokio, former Head of the Espoo Research Centre, decisively contributed to the start of my postgraduate studies and to this thesis. I would like to express my sincere appreciation to him.

My special thanks are due to Miss Oili Uusitalo for excellent technical assistance. Without her intelligence, great diligence and organizing ability the project would not have been carried out in this form. I am also deeply grateful to Mrs. Kirsti Karhunen for creating a friendly working environment and for smooth cooperation, to Marina Niemi, Lic. Phil., for her interest in my work, for encouragement and for constructive criticism of the manuscripts, and to Katri Tiittanen, M.Sc., for introducing me into scientific writing, and for warm interest in my work and never-failing support.

I am grateful to Ulla and Uljas Lehtonen for providing me with two organically cultivated field areas and carrots grown on them. Our discussions were most stimulating, and they broadened my points of view. I also wish to thank all my collaborators, especially Mrs. Ann-Marie Korhonen for skilful typing and for her patience with the corrections, Markku Yli-Halla, Lic. Agr., for constructive criticism of the manuscript, Dr. Pauli Seppänen for valuable discussions, Börje Björkqvist, M.Sc., for advice concerning organic analyses, Veli-Matti Taavitsainen, Lic. Phil., for advice concerning statistical analysis, and the personnel of the Kemira Espoo library for providing me with all the necessary information. I also thank Sevastiana Ruusamo, M.A., for revision of the English text of the articles and this thesis.

My dearest thanks I owe to my husband Ilkka for his encouraging attitude, loving care and never-failing sympathy, and to my parents and brothers with families for their benevolent care and encouraging support of all my attempts throughout the years, which I greatly appreciate. I feel special respect and gratitude to my school teacher Väinö Voutilainen for his imposing native language lessons and for his lasting impact on my academic career.

This work was financially supported by the Academy of Finland and Kemira Oy, which is gratefully acknowledged. Finally, I would like to thank the Scientific Agricultural Society of Finland for including my study in their journal.

Espoo, September 1989 


\section{List of original articles}

The original articles summarized here are:

I Effects of different fertilization practices on the growth, yield and dry matter content of carrot. J. Agric. Sci. Finl. 60: 135-152.

II Effects of different fertilization practices on the carotene content of carrot. J. Agric. Sci. Finl. 61: 7-14.

III Effects of different fertilization practices on the $\mathrm{NO}_{3}-\mathrm{N}, \mathrm{N}, \mathrm{P}, \mathrm{K}, \mathrm{Ca}, \mathrm{Mg}$, ash and dietary fibre contents of carrot. J. Agric. Sci. Finl. 61: 99-111.

IV Effects of different fertilization practices on the glucose, fructose, sucrose, taste and texture of carrot. J. Agric. Sci. Finl. 61: 113-122.

V Effects of different fertilization practices on the quality of stored carrot. J. Agric. Sci. Finl. 61: 123-134.

References to these articles are made in the text by citing the appropriate Roman numerals. 


\section{Contents}

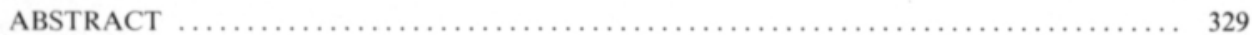

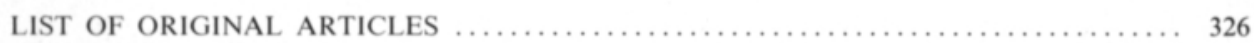

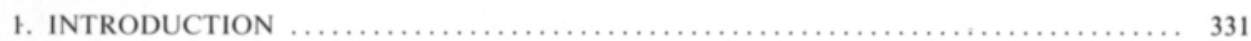

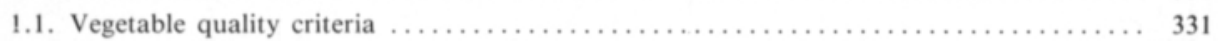

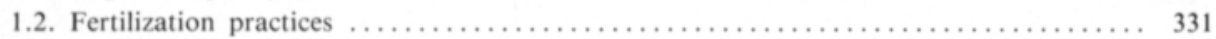

1.2.1. Broadcast vs. placement fertilization .......................... 331

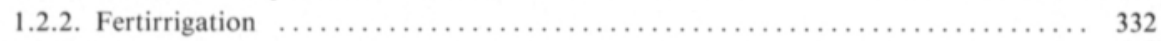

1.3. Effects of fertilization on carrot quality ............................. 333

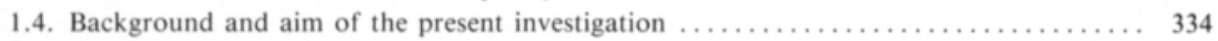

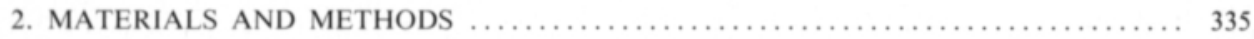

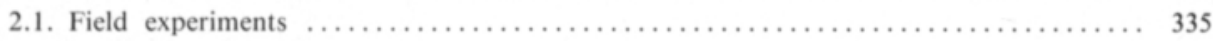

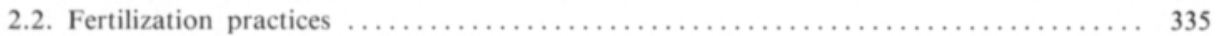

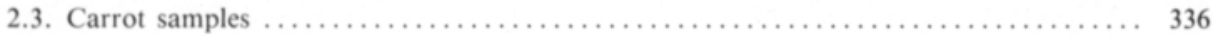

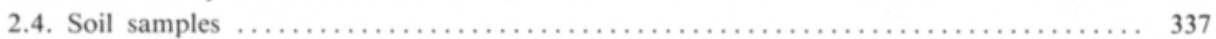

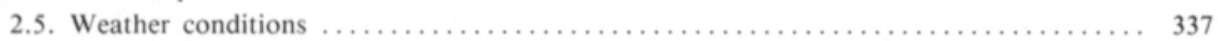

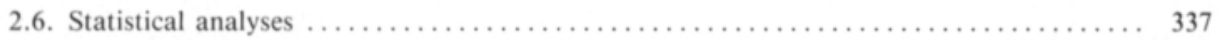

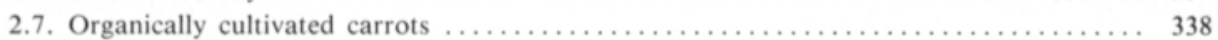

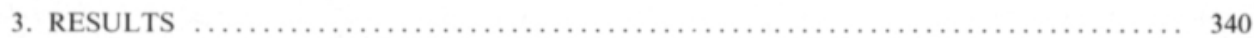

3.1. Effects of fertilization practices on carrot growth and quality . . . . . . . . . . . 340

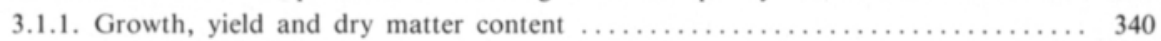

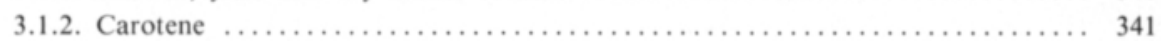

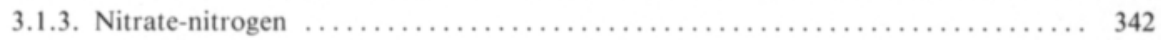

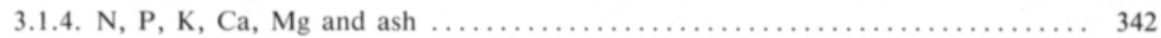

3.1.5. Dietary fibre ........................................... 343

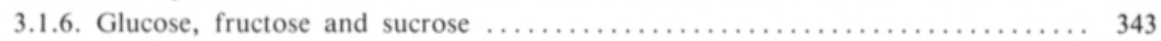

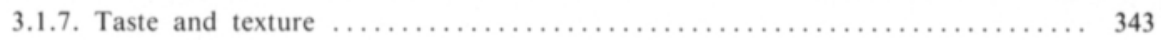

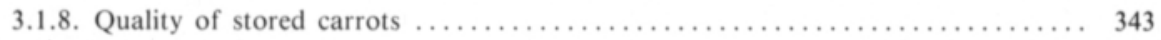

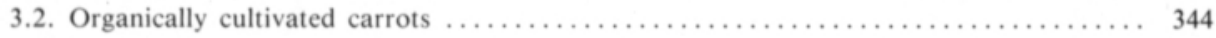

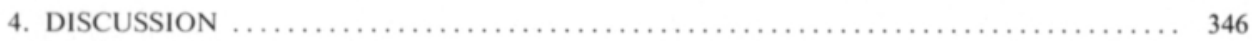

4.1. Growth and quality criteria influenced by fertilization practices $\ldots \ldots \ldots \ldots \ldots \ldots . \ldots \ldots$

4.1.1. Placement fertilization .......................................... 346

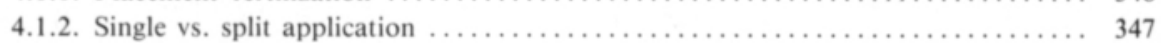

4.1.3. Fertirrigation .............................................. 348

4.2. Quality criteria not or only slightly influenced by fertilization practices ........... 349

4.2.1. Carotene ................................................ 349

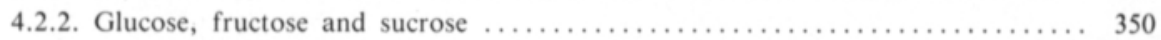

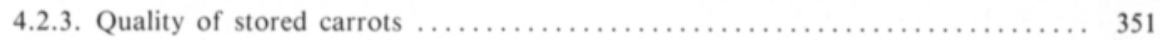

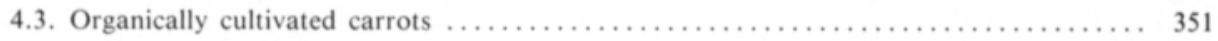

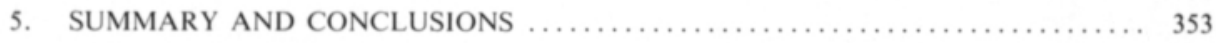

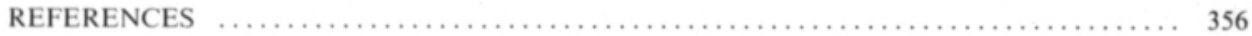





\title{
The role of fertilization practices in the yield and quality of carrot (Daucus carota L.)
}

\author{
AINO-MAIJA EVERS \\ Kemira Oy, Espoo Research Centre \\ Luoteisrinne 2, 02270 Espoo, Finland
}

\begin{abstract}
The influence of different fertilization practices on the growth, yield and inner quality of carrot (Daucus carota L.) was studied. The field experiments were carried out in Southern Finland, on the experimental farm of Kemira Oy, in 1985 and 1986. Unirrigated and irrigated placement and broadcast fertilization, NPK fertirrigations without or with basic fertilization, and PK placement with $\mathrm{N}$ fertirrigations were compared. Placement and broadcast fertilizations were carried out by single application, whereas NPK or N fertirrigations were performed as split applications.

The highest yields were obtained when the total phytomass production was high. The yield increased by the placement of NPK fertilizer as compared to broadcast fertilization, and by the placement of $\mathrm{P}$ and $\mathrm{K}$ as compared to treatments where $\mathrm{P}$ and $\mathrm{K}$ were broadcasted or fertirrigated. The PK placement with $\mathrm{N}$ fertirrigations increased the root dry matter content as compared to NPK fertirrigations. The lowest $\mathrm{NO}_{3}-\mathrm{N}$ contents of roots were obtained by unirrigated placement fertilization. NPK fertirrigations caused higher root $\mathrm{NO}_{3}-\mathrm{N}$ contents than any other fertilization practice, and irrigation as such increased the $\mathrm{NO}_{3}-\mathrm{N}$ contents. Root $\mathrm{N}$ and $\mathrm{P}$ contents were increased by placement of PK or NPK fertilizers, but fertilization practices had no effects on $\mathrm{K}, \mathrm{Mg}$ and $\mathrm{Ca}$ contents. Single application increased ash and dietary fibre contents as compared to split applications. In conclusion, the placement of NPK or PK fertilizers had positive effects on the above mentioned quality criteria and yield, and thus in future research and in commercial vegetable production these fertilization practices should be utilized.

Fertilization practices had no or only slight effects on the carotene and sugar contents, taste, texture and the quality of stored carrots. Carotene content increased as the growing season progressed, and was $41 \%$ higher in the climatically more favourable year 1986 than in 1985. Total sugar contents were higher in the climatically less favourable year 1985 and in unfertilized treatments than in 1986 and in fertilized treatments. It was hypothesized that carrot sugar contents are related to growth and total phytomass production. The indicative results showed that the NPK fertirrigations without basic fertilization had a slight positive effect on carrot taste and texture as compared to placement fertilization but, on the other hand, the NPK fertirrigations without basic fertilization showed a tendency to impair the storage ability as compared to single application. In conclusion, carotene and sugar contents are strongly influenced by genotype and climate and thus it is logical that the effects of fertilization practices remained slight. The results of carrot taste do not allow any final conclusions to be drawn; further investigation on the subject is needed.
\end{abstract}

Index words: fertilization practices, carrot, quality, yield, dry matter, carotene, nutrients, nitrate, ash, dietary fibre, sugars, sensory evaluation, storage 



\section{INTRODUCTION}

\subsection{Vegetable quality criteria}

Modern vegetable cultivation aims to even and high-quality products. Quality can be classified as to outer quality (size, form, colour) and inner quality (nutritionally important factors, nutritionally negative factors, taste and texture). The quality classification is modified case by case, according to each specific purpose for which the vegetables are produced,

The criteria of outer quality are defined in national and international quality and grading standards, and the vegetable marketability and trade are based mainly on these standards. Lack of rapid, inexpensive and reliable measurement technology has made it impossible to classify and price the products according to inner quality. The nutritionally important inner quality criteria include nutritional fibre, sugars, proteins and essential aminoacids, minerals, vitamins and provitamins, organic acids, essential fatty acids and aroma compounds. The nutritionally negative quality criteria include nitrate content, pesticide residues, heavy metal and radioactivity contents, oxalic acid, free amino acids and aroma compounds that give a bad taste, making e.g. the carrot bitter or harsh.

Alternative cultivation methods emphasize the quality criteria differently, and the inner quality is given high priority (SCHUPHAN 1974). Some of the quality factors can be measured by methods known to the natural sciences, but others are more difficult to define and are characterised by a holistic, nonanalytical view of nature (Dцouny 1981).

The quality of vegetables is influenced by genotype, climate and soil as well as by cultivation practices, harvest, storage and market- ing. Different plant species have different optimal growing conditions, and thus the production of high-quality vegetables is an optimization task. Some of the variables can be influenced by a grower, some by plant breeders and some by nature.

\subsection{Fertilization practices}

\subsubsection{Broadcast vs. placement fertilization}

Broadcast fertilization is the most common fertilization practice applied in vegetable cultivation in Finland, though placement fertilizàtion has been shown in many agricultural studies (AUra 1967, KÄHÄrI and EloneN 1969, Pessi et al. 1970, VARIS and LanNetta 1974, Varis 1975, Lyngstad 1977, Esala and LARPES 1986a, 1986b) to increase the yield and the efficiency of fertilizer. Broadcast fertilization for row crops is easy to perform in spring before sowing or planting, but after the foliage has grown, each time a tractor drives through the field some photosynthetasing leaves are damaged. And with common distribution practices, it is not easy to accomplish an even distribution so that every plant obtains an equal amount of nutrients.

Techniques where a solid fertilizer is placed under the soil surface are called row application, banded fertilization or placement fertilization. In these techniques, the fertilizer granules are placed in a band at varying depths under the soil surface, where the moisture conditions remain optimal for granules to dissolve over a longer period of time than in broadcast fertilization. In addition, placement fertilization can increase the fertilizer efficiency, it provides an economical and convenient operation for precise and even distribution, and considering the distance from fertilizer to 
seeds or plants, it can prevent salt damage during germination or early growth (MACLEOD et al. 1975).

Various nutrients are differently suitable for broadcast vs. placement fertilization. Both ammonium and nitrate nitrogen applied to the surface of loam, silt, silt clay, and fine sand clay soils have been shown to remain in the top inch for a considerably long period in dry conditions (KAILA and HÄNNINEN 1961), but in irrigated plots the nitrate nitrogen moves downwards (Aura 1967). This is an obvious phenomenon, as $\mathrm{NO}_{3}-\mathrm{N}$ is unreactive with any ion retaining complexes of soil, it is readily mobile in the soil solution, and it moves primarily vertically as soil water moves. Ammonium nitrogen reacts with the cation exchange complex, becoming absorbed on the surface of soil particles. Mobility is thus diminished (Randall et al. 1985). Consequently, the effect of placement fertilization varies from year to year and is closely related to precipitation or irrigation and to nitrogen application (Aura 1967, LyngSTAD 1977).

It is generally accepted that orthophosphate in soil reacts rapidly with cations, hydrous oxide coatings, or cations in solution to form insoluble compounds, therefore making the mobility of phosphorus insignificant. Thus broadcasted phosphorus concentrates in the surface soil, is susceptible to loss by erosion (Tımmons et al. 1973), and may influence the surface water quality (Young et al. 1985). The plant roots grow in deeper, moist soil layers, and thus the efficiency of broadcasted phosphorus is poor. The placement of phosphorus has been shown to increase the uptake of phosphorus (MACLEOD et al. 1975, MuLKEY et al. 1979) and the efficiency of phosphorus (Pearson and Kirkham 1980, Peterson et al. 1981). Placement of phosphorus has been reported to be most effective at low soil phosphorus levels (Fox and KANG 1978, PETERSON et al. 1981), in dry soil conditions (CHAUDhary and Prihar 1974, Ekeberg 1986), at low soil temperatures (Gingrich 1964, Power et al. 1964), and with granular phosphorus fertilizer (Engelstad and Terman 1980).
It is well established that potassium as a cation is absorbed to cation exchange surfaces and becomes available to plants from soil solution and by contact exchange. Potassium is relatively immobile in soil, having a moderate cation exchange capacity, but in coarse soils it can be leached downwards by rain or irrigation. Potassium in most cases does not react to become unavailable to plants. In dry conditions, broadcasted potassium is not taken up by plants, but in moist conditions plants can utilize it if the roots come into contact with it. Calcium and magnesium are slightly mobile in the soil. They bind to the exchange complex of the soil and act very much like potassium. The plant uptake mechanisms are similar to those for potassium.

\subsubsection{Fertirrigation}

The application of fertilizers in irrigation water is called fertirrigation or fertigation. The advantages of this method are the low costs of energy, labour and equipment, great flexibility in the choice of time and rate of fertilizer application, precise application and distribution of nutrients with some low-pressure systems, and reduced leaching losses of mobile nutrients if the proper application techniques are used. The potential disadvantages are that fertilizer distribution is determined by water distribution; precise application rates are not always possible with some of the water application equipment in current use; fertilizers can be lost in runoff water; nitrogen may be lost by volatilization from $\mathrm{NH}_{4}{ }^{+}$-containing fertilizer applied to the surface of calcareous soils, stratification on the soil surface or localized concentration near the emitter of immobile nutrients (e.g. phosphorus, potassium and some micronutrients) are observed, and precipitation problems may result when some forms of nutrients are introduced into irrigation waters high in $\mathrm{Ca}^{2+}$, $\mathrm{Mg}^{2+}$ and bicarbonate $\mathrm{HCO}_{3}-$ (RANDALl et al. 1985). In spite of disadvantages, the fertirrigation is becoming increasingly popular in the USA (RANDAll et al. 1985). In the Nor- 
dic countries this fertilizer application method is not widely used, mainly because of the variable weather conditions, the need for irrigation varying from year to year and from month to month. Also the irrigation equipment now in use is not especially good for maintaining an even distribution (GREGERSEN 1978). Aura (1983) has proposed that in Finnish conditions fertirrigation is most suitable for plants having a long growing period and taking up nutrients relatively late. Thus vegetables and potatoes grown on coarse soils can produce good yields if fertirrigation is used.

\subsection{Effects of fertilization on carrot quality}

The carrot root dry matter content is unaffected by increasing amounts of nitrogen (Habben 1972, Dragland 1978, Aura 1985, VUORINEN and TAKALA 1987), potassium (HABBEN 1972), organic or inorganic fertilizer (Nilsson 1979), or by irrigation (AurA 1985, VuOrinen and TAKAla 1987). A drought period before harvest increases (Dragland 1978) the carrot root dry matter content and placement fertilization decreases it (Ekeberg 1986), and the differences between years have been greater than the differences between fertilization treatments (Dragland 1978, Aura 1985, Vuorinen and TAKALA 1987).

In the literature there are contradictory reports of the influence of macronutrients on the carotene content. An increasing nitrogen amount either increases the carotene content (Freeman and Harris 1951, Habben 1972), has no effect (Dragland 1978), or it may decrease the carotene content (Southards and Miller 1962). An increasing amount of potassium has no influence on the carotene content (Gallagher 1966, Habben 1972) or increases it (Southards and Miller 1962). The fertilizer level or the use of organic vs. inorganic fertilizers has no effect on the carotene content (NILSSON 1979).

In fertilization experiments, the $\mathrm{NO}_{3}-\mathrm{N}$ contents (Dragland 1978, NilsSON 1979,
LEHTINEN 1984) and the total nitrogen contents in carrots (BISHOP et al. 1973, NiLsson 1979, Lehtinen 1984) have increased systematically with increasing nitrogen amounts. The phosphorus content in carrots has not increased with increasing phosphorus fertilization, but increasing potassium fertilization increases potassium contents in carrots (BISHOP et al. 1973, NiLsson 1979). Reports of the effect of fertilization on the calcium and magnesium contents in carrots have not been published.

The effects of fertilization on the ash and dietary fibre contents have been investigated only a little, but because of the vital role of dietary fibre in human health (SPILler and FreEMAN 1981), this subject ought to be well understood. Increasing nitrogen fertilization decreases the dietary fibre content and increasing potassium fertilization increases the dietary fibre content, but the effects have been relatively small (HABBEN 1972).

Reports of the influence of fertilization on carrot sugar contents in the literature are contradictory. The carrot glucose content increases by increasing nitrogen fertilization (BARNES 1936, HaBben 1972), decreases by increasing potassium fertilization (HABBEN 1972), or remains unaffected by increasing nitrogen (Dragland 1978), phosphorus (BARNES 1936) or potassium fertilization (Gallagher 1966). The carrot fructose content increases by increasing nitrogen fertilization and decreases by increasing potassium fertilization (HaBBen 1972). The carrot sucrose content decreases by increasing nitrogen fertilization (BARnes 1936, Dragland 1978), the sucrose content remains unaffected by nitrogen (HABBEN 1972) or potassium fertilization (Gallagher 1966), and the sucrose content increases by increasing phosphorus (BARNES 1936) or potassium fertilization (HABBen 1972). In Nilsson's (1979) study the glucose, fructose and sucrose contents were unaffected by either the type of fertilizer (organic vs. inorganic) or the amount of fertilizer applied.

The flavour of raw carrots is influenced by 
genotype and environment (SIMON et al. 1982). Sugars and volatile terpenoids are the two major components of carrot flavour (Freeman and Simon 1983), but carrot aroma is very complex, and it is influenced by many compounds (SIMON 1985). Results concerning the effects of fertilization on carrot taste and texture have not been found in the literature.

\subsection{Background and aim of the present investigation}

There are several reasons why the development of fertilization practices is important. Economists have predicted that fertilizers will undoubtly become more expensive in future due to escalating costs of natural gas, labour, mining, exploration, processing and transport (RANDAll et al. 1985), and thus it is very important to improve the efficiency of fertilizers. Trade on national and international vegetable markets requires large quantities of products of even quality. At harvest, each individual vegetable should be of similar size and in the same developmental stage. More precise dosage and application of fertilizer promotes even growth and supplies the plant with nutrients needed at any given time. Growing concern is being voiced by the public towards the impact of fertilizers on the environment. Modern application techniques can play a significant role in preserving the quality of the environment while still producing optimum crops. Techniques to reduce environmental concern almost always result in improved fertilizer efficiency (RANDALL et al. 1985). The primary aim of the present investigation was to study whether the development of fertilization practices affects some of the inner quality criteria of carrot.

In public discussion there is increasing interest in human health and nutrition, and often vegetable quality is considered to depend mainly on modern growing practices and mineral fertilizers. However, also genetic and environmental factors have a certain effect on the quality. The secondary aim of the present investigation was to find out which quality criteria are mainly dependent on genotype and climate, and which on fertilization. 


\section{MATERIALS AND METHODS}

\subsection{Field experiments}

The field experiments were carried out on the Kotkaniemi Experimental Farm of Kemira Oy in Vihti, Southern Finland $\left(60^{\circ} 22^{\prime} \mathrm{N}\right.$, $24^{\circ} 22^{\prime} \mathrm{E}$ ) during the growing seasons of 1985 and 1986 . The carrot variety grown in this experiment was cv. Nantes Duke Notabene 370 Sv which is commonly grown for the food industry in Finland. Coated seeds (I) were sown $1 \mathrm{~cm}$ deep at a row distance of $50 \mathrm{~cm}$ and plants were thinned later to 30 plants $/ \mathrm{m}$. Weeds were sprayed with promethryn twice per growing season. Sypermetrin was used for protection against carrot psyllit, Trioza apicalis $\mathrm{F}$. The carrots were harvested manually, and $8 \mathrm{~kg}$ of sample per plot in 1985 and 15 $\mathrm{kg}$ in 1986 were stored in refrigerated storage $\left(0 \ldots+1.5^{\circ} \mathrm{C}, \mathrm{RH} 90-95 \%\right)$ for six months and four months, respectively.

\subsection{Fertilization practices}

In the field experiments, ten treatments were compared (Table 1). In the case of unirrigated and irrigated controls, no annual fertilization was applied. In the original articles $\mathrm{I}-\mathrm{V}$ these have been called unfertilized treatments.

In broadcast and placement practices (Table 1), all nutrients were given as a single application in spring, before sowing. Placement fertilization was done with a fertilizer drill.

Table 1. The fertilization treatments and the total amounts of nutrients and irrigation water.

\begin{tabular}{|c|c|c|c|c|c|}
\hline \multirow[t]{2}{*}{ Treatment } & \multirow[t]{2}{*}{$\begin{array}{l}\text { Number and time of } \\
\text { fertilizer applications }\end{array}$} & \multicolumn{3}{|c|}{$\begin{array}{c}\text { Macronutrient } \\
\text { amounts in } 1986^{3} \\
\mathrm{~kg} / \mathrm{ha}\end{array}$} & \multirow{2}{*}{$\begin{array}{c}\text { Irrigation water } \\
\text { amounts in } 1985 \\
\text { and } 1986 \\
\text { mm }\end{array}$} \\
\hline & & $\mathrm{N}$ & $\mathrm{P}$ & K & \\
\hline \multicolumn{6}{|l|}{ Unfertilized } \\
\hline Unirrigated & 0 & 0 & 0 & 0 & 0 \\
\hline Irrigation & 0 & 0 & 0 & 0 & $3 \times 10$ \\
\hline \multicolumn{6}{|l|}{ NPK placement } \\
\hline Unirrigated & Once before sowing & 80 & 35 & 133 & 0 \\
\hline Irrigation & Once before sowing & 80 & 35 & 133 & $3 \times 10$ \\
\hline \multicolumn{6}{|l|}{ NPK broadcast } \\
\hline Unirrigated & Once before sowing & 80 & 35 & 133 & 0 \\
\hline Irrigation & Once before sowing & 80 & 35 & 133 & $3 \times 10$ \\
\hline \multicolumn{6}{|l|}{ NPK fertirrigations } \\
\hline No basic & Three times during the season & 80 & 29 & 160 & $3 \times 10$ \\
\hline Half the basic ${ }^{\prime}$ & $\begin{array}{l}\text { Once before sowing and } \\
\text { three times during the season }\end{array}$ & 80 & 32 & 142 & $3 \times 10$ \\
\hline \multicolumn{6}{|l|}{ PK placement ${ }^{2}$} \\
\hline $3 \mathrm{~N}$-fertirrigations & $\begin{array}{l}\text { Once before sowing and } \\
\text { three times during the season }\end{array}$ & 81 & 56 & 133 & $3 \times 10$ \\
\hline $4 \mathrm{~N}$-fertirrigations & $\begin{array}{l}\text { Once before sowing and } \\
\text { four times during the season }\end{array}$ & 155 & 56 & 133 & $4 \times 10$ \\
\hline
\end{tabular}

1 Half of the nutrients were given in basic placement fertilization and half in NPK fertirrigations.

2 Phosphorus and potassium were given in basic placement fertilization and nitrogen in fertirrigations.

3 The nutrient amounts were $30 \%$ higher in 1985 than in 1986. 
The fertilizer row distance was $50 \mathrm{~cm}$, and the seeds were sown afterwards, $3 \mathrm{~cm}$ beside the fertilizer row. In the broadcast method the fertilizer was spread on the soil surface manually and harrowed in with a rotary cultivator.

The NPK fertirrigations and PK placement with $\mathrm{N}$ fertirrigations (Table 1) were split applications, in other words, the nutrients were given periodically three to five times during the growing season. In NPK fertirrigations, a water-soluble fertilizer was dissolved in water, and all or half of the nutrient amount was spread with a self-made boom. In PK placement with $\mathrm{N}$ fertirrigations, the phosphorus and potassium were given by the placement method with a fertilizer drill in spring before sowing, and nitrogen was given by nitrogen fertirrigations during the growing season.

All fertilized treatments received the same amount of nitrogen except PK placement with $4 \mathrm{~N}$ fertirrigations which received a supraoptimal amount of nitrogen (Table 1). The PK placement treatments received a greater amount of phosphorus owing to the phosphorus content of the granular fertilizer used in the experiments. The amount of potassium was somewhat greater in the NPK fertirrigation treatment owing to the fertilizer used. The micronutrient fertilizations are given in the original article I. Irrigated placement and broadcast fertilized treatments received the same amounts of water as the fertirrigated treatments (Table 1).

\subsection{Carrot samples}

In 1985, carrot root and shoot samples were collected three times during the growing season (Table 2) for determination of fresh and dry weight and $\mathrm{NO}_{3}-\mathrm{N}$, total $\mathrm{N}, \mathrm{P}, \mathrm{K}, \mathrm{Ca}$, and $\mathrm{Mg}$ contents. Carrot root samples were collected at harvest for yield, for determination of carotene, glucose, fructose and sucrose, and for sensory evaluation, e.g. taste and texture. After the storage period, the marketable yield and weight loss were weighed, the carotene content was determined, and sensory evaluation for taste and texture was performed.

In 1986, carrot root and shoot samples were collected three times during the growing season (Table 2) for determination of fresh and dry weight and $\mathrm{NO}_{3}-\mathrm{N}$ content, and root samples were collected for determination of carotene content. Carrot root and shoot samples were collected at harvest for determination of $\mathrm{N}, \mathrm{P}, \mathrm{K}, \mathrm{Ca}, \mathrm{Mg}$ and ash contents, and root samples for determination of yield, dietary fibre, glucose, fructose and sucrose contents, and for sensory evaluation, e.g. taste and texture. After the storage period, the marketable yield and weight loss were weighed, the carotene, $\mathrm{NO}_{3}-\mathrm{N}, \mathrm{N}, \mathrm{P}, \mathrm{K}, \mathrm{Ca}, \mathrm{Mg}$, ash, glucose, fructose and sucrose contents were determined, and sensory evaluation for taste and texture was performed. The sample size for yield was $8 \mathrm{~m}^{2}$, i.e. 16 row metres per plot. Other sample sizes are shown in Table 3.

Table 2. The schedule for fertilization, sowing, sampling, harvest and storage.

\begin{tabular}{|c|c|c|c|c|}
\hline & \multicolumn{2}{|c|}{ Fertilizer experiment } & \multicolumn{2}{|c|}{ Organic cultivation } \\
\hline & 1985 & 1986 & Location 1 & Location 2 \\
\hline Basic fertilization & 4 June 1985 & 6 June 1986 & 14 May 1986 & 21 May 1986 \\
\hline First fertirrigation or irrigation & 14 June 1985 & 29 June 1986 & & \\
\hline Second fertirrigation or irrigation & 5 July 1985 & 10 July 1986 & & \\
\hline Third fertirrigation or irrigation & 19 July 1985 & 24 July 1986 & & \\
\hline Fourth fertirrigation or irrigation & 2 Aug. 1985 & 7 Aug. 1986 & & \\
\hline Sowing & 8 June 1985 & 9 June 1986 & 14 May 1986 & 21 May 1986 \\
\hline First plant sampling & 20 Aug. 1985 & 12 Aug. 1986 & 14 Aug. 1986 & 14 Aug. 1986 \\
\hline Second plant sampling & 10 Sept. 1985 & 3 Sept. 1986 & 1 Sept. 1986 & 1 Sept. 1986 \\
\hline Harvest & 30 Sept. 1985 & 6 Oct. 1986 & 25 Sept. 1986 & 25 Sept. 1986 \\
\hline End of storage & 2 April 1986 & 23 Dec. 1987 & 23 Feb. 1987 & 23 Feb. 1987 \\
\hline
\end{tabular}


Table 3. The carrot sample sizes in the experiments of 1985 and 1986.

\begin{tabular}{lcc}
\hline & \multicolumn{2}{c}{ Sample size } \\
\cline { 2 - 3 } & $\begin{array}{c}\text { Carrots } \\
\text { per } \\
\text { plot }\end{array}$ & $\begin{array}{c}\text { Carrots } \\
\text { per } \\
\text { treatment }\end{array}$ \\
\hline 1985 & & \\
Root and shoot & & \\
fresh and dry weight & 20 & 80 \\
NO- N & 10 & $20^{*}$ \\
N, P, K, Ca, Mg & 10 & $20^{*}$ \\
Root carotene & 6 & $12^{*}$ \\
glucose, fructose, sucrose & 5 & $10^{*}$ \\
taste and texture & 10 & $20^{*}$ \\
1986 & & \\
Root and shoot & & \\
fresh and dry weight & 20 & 80 \\
NO ${ }_{3}-\mathrm{N}$ & 20 & 80 \\
N, P, K, Ca, Mg, ash & 5 & 20 \\
Root carotene & 6 & 24 \\
dietary fibre & 5 & 20 \\
glucose, fructose, sucrose & 5 & 20 \\
taste and texture & 10 & 40 \\
\hline
\end{tabular}

* Carrots were collected from two blocks only.

In 1985, samples for determination of quality were collected from two blocks only. A heavy rain in June 1985 caused a crust on the soil surface, as a result of which the plantation was uneven in two blocks which were omitted.

The methods used to analyse the plants are described or referred to in the following original articles:

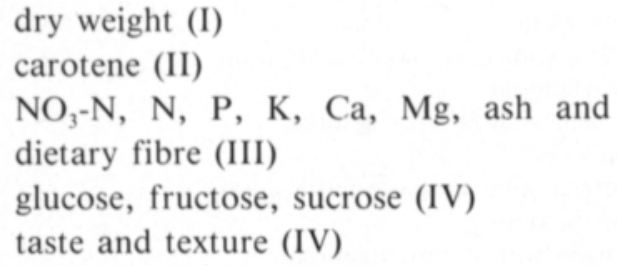

\subsection{Soil samples}

The soil in the experimental field was fine sand with $15-30 \%$ clay and a humus content of $12-20 \%$. Soil samples were collected across the carrot row from a soil layer $15 \mathrm{~cm}$ deep. Samples were taken two days before sowing and $6,27,41,54,76,96$ and 116 days after sowing in 1985. In 1986, the samples were taken one day before sowing and 18, 31, 46,65 and 117 days after sowing. Soil samples were collected and analysed as described in the original article I. The chemical characteristics of the soil in spring before fertilization are given in the original article I, Table 4 , those during growing seasons are given in the original article I, Figure 5.

\subsection{Weather conditions}

The weather conditions were unfavourable in June and July 1985 (I/Table 3). The mean day temperature and the number of sunshine hours were lower than the long-term averages. On 16 June, heavy rain came only two days after the first irrigation, when seedlings had begun to emerge. The heavy rain caused a crust to form on the soil surface, and the crust hindered the emergence of seedlings. In August and September 1985, weather conditions were moderate, but the soil was too wet.

In 1986, June was very warm and sunny. The mean day temperature and the number of sunshine hours were above the long-term averages (I/Table 3 ). The precipitation was only $28 \mathrm{~mm}$, and the soil was dry. July was favourable for growth. August and September were cold and rainy, and thus unfavourable for growth. Altogether, 1985 was a less favourable year for growth than 1986 .

\subsection{Statistical analyses}

The field experiments were set up according to the method of completely randomized blocks. There were four blocks, ten treatments and thus totally 40 plots.

The results were studied statistically by contrast analysis (STEel and Torrie 1980). The two years were studied separately (II-V), except in the original article I. The partitioning of treatments into contrasts are presented in Table 4. The unfertilized, placement and broadcast fertilized treatments were also studied by the analysis of variance as a factorial experiment. The fertilization levels were 1) no 
fertilization, 2) placement fertilization, and 3) broadcast fertilization. The irrigation levels were 1) no irrigation and 2) irrigation. The significance of differences between means were tested with the Duncan test or with StudentNeuman-Keul's test (STEel and TORrie 1980). The Pearson's product moment correlation coefficients ( $r$ ) were calculated to measure the strength and direction of the linearity between the variables.

The differences were considered to be statistically significant at the $5 \%$ level, and were marked with asterisks as follows:

* $\quad$ significant at $5 \%$ level, $\mathrm{p} \leq 0.05$

** significant at $1 \%$ level, $\mathrm{p} \leq 0.01$

*** significant at $0.1 \%$ level, $\mathrm{p} \leq 0.001$

The differences were regarded to show a tendency at the $10 \%$ level, $\mathrm{p} \leq 0.1$.

\subsection{Organically cultivated carrots}

In 1986, simultaneously with the fertilization experiment, samples from two organically cultivated fields were collected. These were grown from the same seed material, but the geographical position, climate and soil characteristics were different. The aim of this sampling was to obtain some data on organically cultivated carrots and soils, but they were not compared statistically with the results of the fertilization experiment.

Organically cultivated fields were located in Central Finland. At location one, the field had been cultivated organically for five years, at location two for 20 years. The field works were done manually, and they were home gardens. They were fertilized with compost (I/Table 2) and sown in May (Table 2). No herbicides or pesticides were used, but Agryl cloth was spread over the plantation to prevent insect damage. The row distance was $25-30 \mathrm{~cm}$, and plants were thinned to 25 plants $/ \mathrm{m}$. Carrots were harvested manually, and a $15 \mathrm{~kg}$ sample was stored in the same refrigerated storage as the carrots for the fertilization experiment. Carrot and soil samples were collected and analysed similarly to those

Table 4. The partitioning of treatments to contrasts.

Unfertilized

Not irrigated

Normal N, split

Placement fertilization

Placement fertilization

Placement fertilization

Placement fertilization

Placement fertilization

Broadcast fertilization

Broadcast fertilization

Broadcast fertilization

Broadcast fertilization

Single application

Single application

Single application

Single application

Irrigated single application

Irrigated single application

Irrigated single application

Irrigated single application

Unirrigated single application

Unirrigated single application

Unirrigated single application

Unirrigated single application

$\mathrm{P}$ and $\mathrm{K}$ placement fertilization

$\mathrm{PK}$ placement with $\mathrm{N}$ fertirrigations

$\mathrm{PK}$ placement with $\mathrm{N}$ fertirrigations
vs. Fertilized
vs. Irrigated
vs. Big amount $\mathrm{N}$, split
vs. Broadcast fertilization
vs. Split application
vs. NPK fertirrigations, no basic fertilization
vs. NPK fertirrigations
vs. $\mathrm{PK}$ placement with $\mathrm{N}$ fertirrigations
vs. Split application
vs. NPK fertirrigations, no basic fertilization
vs. NPK fertirrigations
vs. PK placement with $\mathrm{N}$ fertirrigations
vs. Split application
vs. NPK fertirrigations, no basic fertilization
vs. NPK fertirrigations
vs. PK placement with $\mathrm{N}$ fertirrigations
vs. Split application
vs. NPK fertirrigations, no basic fertilization
vs. NPK fertirrigations
vs. PK placement with $\mathrm{N}$ fertirrigations
vs. Split application
vs. NPK fertirrigations, no basic fertilization
vs. NPK fertirrigations
vs. PK placement with $\mathrm{N}$ fertirrigations
vs. $P$ and $K$, no placement fertilization
vs. NPK fertirrigations, no basic fertilization
vs. NPK fertirrigations 
taken for the fertilization experiment. The soil in the organically cultivated fields was fine sand moraine, with a humus content of
$3-6 \%$ in location one and of $12-20 \%$ in location two. Weather condition data were not collected. 


\section{RESULTS}

\subsection{Effects of fertilization practices on carrot growth and quality}

\subsubsection{Growth, yield and dry matter content}

The root and shoot dry weights were positively correlated on all sampling dates of both years (Fig. 1). Thus the root dry weight was high when the total phytomass production was great. In other words, the big photosynthetizing apparatus provided plenty of photosynthates for the growing root.

The fertilization practices with a high root to shoot dry weight ratio were placement fertilization and NPK fertirrigations without basic fertilization. In other words, these treatments favoured root growth in relation to shoot growth. Unirrigated broadcast fertilization had a low root to shoot dry weight ratio, which indicates that this treatment favoured shoot growth in relation to root growth (I/Fig. 4). The calculated root to shoot ratios did not, however, correlate with yield, as the ratio may be high even though the absolute root yield was relatively small, as was the case in NPK fertirrigations without basic fertilization. This treatment had a high root to shoot ratio, but only a moderate yield (I).

The highest yields were achieved with placement fertilization as compared to broadcast fertilization. The yields were also high when phosphorus and potassium were applied by placement fertilization as compared to the treatments where $\mathrm{P}$ and $\mathrm{K}$ were broadcasted or fertirrigated (Table 5). Thus it can be assumed that the yield increase was due to the placement of phosphorus or potassium. Because granular NPK or PK fertilizers were used, it is not possible to distinguish between the effects of phosphorus and potassium.

Table 5. The effect of different fertilization practices on the carrot dry matter content and total yield, as well as standard errors.

\begin{tabular}{|c|c|c|c|c|c|c|}
\hline \multirow[t]{2}{*}{ Treatment } & \multicolumn{3}{|c|}{$\begin{array}{l}\text { Dry matter content } \\
\qquad \%\end{array}$} & \multicolumn{3}{|c|}{$\begin{array}{c}\text { Yield } \\
\text { tons/ha }\end{array}$} \\
\hline & 1985 & 1986 & Average & 1985 & 1985 & Average \\
\hline \multicolumn{7}{|l|}{ No fertilization } \\
\hline No irrigation & $9.4 \pm 0.1$ & $10.7 \pm 0.1$ & 10.1 & $36.4 \pm 3.1$ & $47.6 \pm 1.5$ & 42.0 \\
\hline Irrigation & $9.5 \pm 0.2$ & $10.7 \pm 0.1$ & 10.1 & $32.0 \pm 3.0$ & $45.8 \pm 5.4$ & 38.9 \\
\hline \multicolumn{7}{|l|}{ NPK placement } \\
\hline No irrigation & $9.7 \pm 0.3$ & $10.5 \pm 0.2$ & 10.1 & $37.7 \pm 2.7$ & $50.6 \pm 2.4$ & 44.2 \\
\hline Irrigation & $9.3 \pm 0.2$ & $10.3 \pm 0.2$ & 9.8 & $38.6 \pm 1.5$ & $56.6 \pm 3.4$ & 47.6 \\
\hline \multicolumn{7}{|l|}{ NPK broadcast } \\
\hline No irrigation & $9.4 \pm 0.3$ & $10.6 \pm 0.2$ & 10.0 & $37.1 \pm 2.9$ & $48.2 \pm 1.8$ & 42.7 \\
\hline Irrigation & $9.6 \pm 0.2$ & $10.3 \pm 0.1$ & 9.9 & $25.9 \pm 2.6$ & $48.2 \pm 4.8$ & 37.1 \\
\hline \multicolumn{7}{|l|}{ NPK fertirrigation } \\
\hline No basic & $9.2 \pm 0.3$ & $10.3 \pm 0.2$ & 9.8 & $35.1 \pm 5.9$ & $52.1 \pm 3.7$ & 43.6 \\
\hline Half the basic & $9.4 \pm 0.1$ & $10.5 \pm 0.2$ & 10.0 & $36.0 \pm 2.1$ & $55.0 \pm 1.6$ & 45.5 \\
\hline \multicolumn{7}{|l|}{ PK placement } \\
\hline $3 \mathrm{~N}$ fertirrigation & $9.6 \pm 0.1$ & $10.8 \pm 0.1$ & 10.2 & $39.8 \pm 2.0$ & $48.4 \pm 6.5$ & 44.1 \\
\hline $4 \mathrm{~N}$ fertirrigation & $9.6 \pm 0.2$ & $10.5 \pm 0.2$ & 10.1 & $37.7 \pm 1.8$ & $52.6 \pm 2.2$ & 45.2 \\
\hline Average yield & $9.5 \pm 0.4$ & $10.5 \pm 0.2$ & 10.0 & $35.6 \pm 3.3$ & $50.5 \pm 3.7$ & 43.1 \\
\hline
\end{tabular}



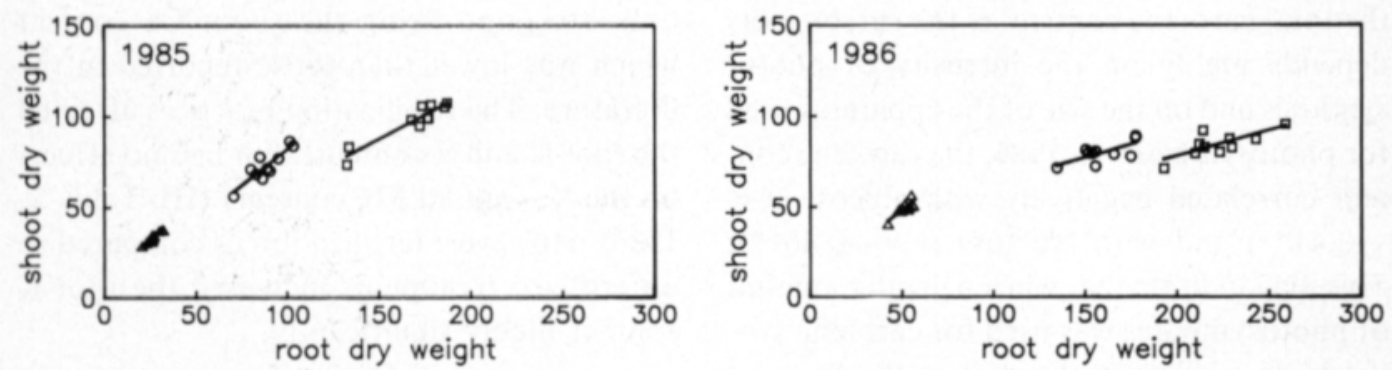

Fig. 1. The correlations of root and shoot dry weights in 1985 and 1986 on three different sampling dates, $\Delta$ two months after sowing, $O$ three months after sowing and $\square$ four months after sowing.

Placement fertilization increased also the phosphorus content of carrot roots as compared to broadcast fertilization, NPK fertirrigations with or without basic fertilization or split application in 1986 (III/Table 2). The soil phosphorus levels were low in all treatments (I/Fig. 5).

The root dry matter contents obtained in the present study are in agreement with the literature in the sense that the differences in root dry matter content were greater between years than between fertilization practices, and that the nitrogen amount did not affect the root dry matter content (I). In both years, the root dry matter content was higher in the PK placement with $\mathrm{N}$ fertirrigation treatments than in the NPK fertirrigation treatments (I). Thus the placement of phosphorus and potassium increased not only the yield but also the dry matter content of carrots.

The parameters that correlated with root dry matter content were root sucrose content $\left(1985 \mathrm{r}=0.84^{*}\right)$, root total sugar content (1985 $\left.\mathrm{r}=0.95^{* *}, 1986 \mathrm{r}=0.39^{*}\right)$ and shoot $\mathrm{NO}_{3}-\mathrm{N}$ content $(1985 \mathrm{r}=-0.71$ with $\mathrm{p} \leq 0.07,1986$ $\left.\mathrm{r}=-0.32^{*}\right)$. Carbohydrates form the major dry matter component in carrot, as Soucl et al. (1979) reported that $100 \mathrm{~g}$ carrot fresh weight contains $88.2 \mathrm{~g}$ water, $0.98 \mathrm{~g}$ protein, $0.20 \mathrm{~g}$ lipids, $8.71 \mathrm{~g}$ carbohydrates, $1.05 \mathrm{~g}$ raw fibre, and $0.86 \mathrm{~g}$ minerals. Glucose, fructose and sucrose account for $91 \%$ of the total sugars in carrot (Alabran and MABrouk 1973). Sucrose is the most abundant sugar in carrot (Alabran and Mabrouk 1973, Simon et al. 1982). Thus it is most natural that the in- creased dry matter content depends on increased sucrose and total sugar amounts.

\subsubsection{Carotene}

Fertilization practices showed some tendency $(\mathrm{P} \leq 0.1)$ to affect the carrot carotene content in the less favourable year of 1985 (II). The PK placement with $\mathrm{N}$ fertirrigations tended to yield a higher carotene content than did broadcast fertilization, irrigated single application and NPK fertirrigations. There was also a tendency to a higher carotene content when $\mathrm{P}$ and $\mathrm{K}$ were placement fertilized, as compared to treatments where $\mathrm{P}$ and $\mathrm{K}$ were not placement fertilized. In the climatically more favourable year of 1986, fertilization practices had no effects or tendencies on the carotene content at harvest.

Weather conditions had a strong effect on the carotene content of carrots; the average carotene content was $41 \%$ higher in 1986 than in 1985 (II/Fig. 1). The carotene content increased with advancing growing season (II/Fig. 2).

In 1985 , carotene correlated positively with root dry matter percentage $\left(r=0.78^{*}\right)$ and negatively with the root to shoot ratio $(r=$ $-0.75^{*}$ ). In other words, the carotene content was high when the shoot fresh weight was great in relation to root fresh weight. This is in agreement with BANGA and De BruYN (1964), who reported the same correlations. They concluded that the percentage of dry matter can be seen as an indicator of the intensity of photosynthesis, and it appears that 
the total carotene content of the carrot roots depends highly on the intensity of photosynthesis and on the size of the apparatus used for photosynthesis. In 1986, the carotene content correlated negatively with glucose $(r=$ $\left.-0.41^{* *}\right)$ and with fructose $\left(r=-0.46^{* *}\right)$. This may indicate that when a greater amount of photosynthates was used for carotene synthesis, less is left in the root in the form of glucose and fructose.

\subsubsection{Nitrate-nitrogen}

Fertilization practices affected the $\mathrm{NO}_{3}-\mathrm{N}$ contents of carrots (III). In both years the highest $\mathrm{NO}_{3}-\mathrm{N}$ contents in carrot roots were found in NPK fertirrigations without basic fertilization treatment, and the lowest contents in unirrigated placement fertilized treatment (IIIa/Tables 2 and 3, III/Fig. 2a). In 1986, the irrigation increased the root $\mathrm{NO}_{3}-\mathrm{N}$ content as compared to unirrigated treatments. Thus part of the difference found between NPK fertirrigations without basic fertilization and unirrigated placement fertilization may be due to irrigation. The relatively high $\mathrm{NO}_{3}-\mathrm{N}$ content in NPK fertirrigations without basic fertilization treatment cannot be caused only by the nitrogen application method or irrigation, because the $\mathrm{NO}_{3}-\mathrm{N}$ contents were lower in both years in PK placement with $\mathrm{N}$ fertirrigations. Thus the placement of $\mathrm{P}$ and $\mathrm{K}$ may have had a positive effect on the $\mathrm{NO}_{3}-\mathrm{N}$ content of carrot roots. Split application did not differ from single application. The $\mathrm{NO}_{3}-\mathrm{N}$ contents were low as compared to the findings reported in the literature (III), and there was a clear difference between years (III/Table 2).

\subsection{4. $\mathrm{N}, \mathrm{P}, \mathrm{K}, \mathrm{Ca}, \mathrm{Mg}$ and ash}

The effects of different fertilization practices on the macronutrient and ash contents in carrot shoots and roots were studied in 1986 (III). The mean macronutrient contents detected in shoots and roots were in good agreement with those reported in the literature, the only exception being the shoot $\mathrm{Ca}$ content which was lower than those reported in the literature. The fertilization practices affected the root $\mathrm{N}$ and $\mathrm{P}$ contents, but had no effects on the $\mathrm{K}, \mathrm{Ca}$ and $\mathrm{Mg}$ contents (III/Table 2, 1986). However, fertilization as compared to unfertilized treatments increased the root $\mathrm{K}$ content highly significantly.

Fertilization increased the $\mathrm{N}$ content of roots, and the $\mathrm{N}$ content was higher with $\mathrm{PK}$ placement with $\mathrm{N}$ fertirrigations as compared to NPK fertirrigations without basic fertilization or to NPK fertirrigations (III/Tables 2 and 3,1986 ). In these treatments, $\mathrm{N}$ was given by split fertirrigations; thus the $\mathrm{N}$ application method cannot be the reason for the higher $\mathrm{N}$ content in $\mathrm{PK}$ placement with $\mathrm{N}$ fertirrigations. The contrast PK placement with $\mathrm{N}$ fertirrigations also includes the supraoptimal $\mathrm{N}$ amount, which had a slightly higher root $\mathrm{N}$ content (III/Table 2, 1986), but this was not statistically significant. The placement of PK fertilizer probably had a favourable effect on $\mathrm{N}$ uptake.

In the $\mathrm{P}$ contents of carrot root there were many significant differences between fertilization practices in 1986 (III). From these results it can be concluded that the placement of NPK or PK fertilizer increased the root P contents. NPK fertirrigations without basic fertilization yielded a lower $\mathrm{P}$ content than did any other treatment except broadcast fertilization.

Fertilization increased the ash content as compared to the unfertilized treatments. Placement fertilization, single application and unirrigated single application yielded a higher ash content than did split applications, NPK fertirrigations and $\mathrm{PK}$ placement with $\mathrm{N}$ fertirrigations (III). In 1986, the root ash content correlated with root $\mathrm{N}$ content $(\mathrm{r}=$ $\left.0.437^{* *}\right)$, root $\mathrm{K}$ content $\left(\mathrm{r}=0.393^{*}\right)$, root $\mathrm{Ca}$ content $(\mathrm{r}=-0.289, \mathrm{p}=0.07)$, dietary fibre $\left(r=0.340^{*}\right)$, total sugar content $(r=-0.306$, $\mathrm{p}=0.06)$ root dry matter content $(\mathrm{r}=$ $\left.-0.355^{*}\right)$, shoot $\mathrm{NO}_{3}-\mathrm{N}$ content $(\mathrm{r}=0.282$, $\mathrm{p}=0.08)$, shoot $\mathrm{N}$ content $\left(\mathrm{r}=0.5^{* *}\right)$, shoot 
$\mathrm{K}$ content $(\mathrm{r}=0.275, \mathrm{p}=0.09)$ and shoot $\mathrm{Ca}$ content $(-0.299, \mathrm{p}=0.06)$.

\subsubsection{Dietary fibre}

Fertilization, irrigation and fertilization practices had favourable effects on the dietary fibre contents of carrots (III). Fertilization and irrigation increased the dietary fibre content as compared to unfertilized and unirrigated treatments, respectively. Irrigated single application increased the dietary fibre content as compared to split application and PK placement with $\mathrm{N}$ fertirrigations.

The significant correlation coefficients between dietary fibre and the other determined criteria were: marketable yield $0.31^{*}$, root fresh weight $0.38^{*}$, root dry weight $0.32^{*}$, root ash content $0.34^{*}$, shoot $\mathrm{N}$ content $0.38^{*}$, shoot $\mathrm{K}$ content $0.38^{*}$, fructose $-0.34^{*}$ and total sugars $-0.44^{* *}$. Good growth and nutrient uptake thus seem to promote the dietary fibre content. In treatments where a considerable amount of photosynthates has been used for phytomass production, it is logical that simultaneously less sugars were found in storage root.

\subsubsection{Glucose, fructose and sucrose}

In 1985 or 1986 there were no statistically significant differences between fertilization practices in the glucose, fructose or sucrose contents at harvest. Only a tendency $(\mathrm{p}<0.1)$ could be seen that placement fertilization increased the glucose content as compared to NPK fertirrigations (IV).

The glucose, fructose and total sugar contents in fresh weight were higher in 1985 than in 1986, whereas the opposite was true for the sucrose content, which was higher in 1986 than in 1985 (IV). In 1986, the unfertilized treatments had a tendency to yield higher glucose and fructose contents than did the fertilized treatments, on average, but there were no differences or tendencies in the sucrose content. The total sugar content and the calculated value for the sweetness of sugars was higher in unfertilized treatments than in fertilized treatments (IV).

\subsubsection{Taste and texture}

In both years, NPK fertirrigations without basic fertilization produced significantly better taste at harvest than did placement fertilization (IV), but the absolute differences between treatments were small. The significant differences also in other contrasts confirmed that the placement of NPK or PK fertilizer had an unfavourable effect on the taste (IV). One factor that might influence this result is the water given with NPK fertirrigations. Although irrigated treatments did not have a significantly better taste as compared to unirrigated treatments, in both years, however, the irrigated placement fertilized carrots had better taste scores than did unirrigated placement fertilized carrots.

No significant differences in carrot texture were found in 1985. In 1986, the taste and texture scores were closely correlated (IV). It is obvious that the sensory panel cannot distinguish taste and texture from each other, and texture does affect the perception of taste. The treatments that gave good taste results also gave good texture results. The only addition was that not only placement fertilization but also single application yielded worse texture than NPK fertirrigations.

\subsubsection{Quality of stored carrots}

There were only a few effects of fertilization practices on the quality of stored carrots (V/Table 5). In 1986, after storage, the unfertilized treatments had higher marketable yield, less weight loss, lower $\mathrm{NO}_{3}-\mathrm{N}, \mathrm{N}, \mathrm{K}$ and ash contents than fertilized treatments. In 1986, after storage, irrigation decreased the marketable yield as compared to unirrigated treatments. The irrigated placement and broadcast fertilized treatments had high $\mathrm{K}$ contents after storage.

Some tendencies, at the level of $\mathrm{p} \leq 0.1$, were observed. In 1985, after storage, NPK 
fertirrigations without basic fertilization showed a tendency to produce a lower marketable yield than did single application and placement fertilization. In 1986, after storage, split application and NPK fertirrigations showed a tendency to produce a lower marketable yield than did unirrigated single application. The reason for this may be the water given with split and NPK fertirrigation treatments, because in 1986 irrigation was shown to decrease the marketable yield. The supraoptimal $\mathrm{N}$ amount showed a tendency to yield a higher carotene content than did the optimal $\mathrm{N}$ amount, and NPK fertirrigations a lower $\mathrm{NO}_{3}-\mathrm{N}$ content than the irrigated single application.

In both years, the stored carrots were heavily infected by Centrospora rot, Mycocentrospora acerina (R. Hartig) Deighton, a soilborne disease. This was the main reason for the poor storage ability.

According to the results of the present in- vestigation, fertilization had a negative effect on the storage ability as compared to unfertilized treatments, and this effect was greater than the effects of different fertilization practices.

\subsection{Organically cultivated carrots}

At harvest, the organically cultivated carrots had higher carotene, $\mathrm{P}, \mathrm{Mg}$ and glucose contents than carrots in the fertilized treatments in the fertilization experiment in 1986, when the means of these two groups were compared (Table 6). There were no or only slight differences in the root dry matter content, in the ash, fructose, sucrose, total sugar contents and in texture. On the other hand, the organically cultivated carrots had lower yield, lower $\mathrm{NO}_{3}-\mathrm{N}, \mathrm{N}, \mathrm{K}$ and $\mathrm{Ca}$ contents, and worse taste than carrots in the fertilized treatments in the fertilization experiment.

Table 6. Comparison of measured yield and quality parameters for organically and conventionally cultivated carrots at harvest.

\begin{tabular}{|c|c|c|c|c|c|}
\hline \multirow[t]{2}{*}{ At harvest } & \multicolumn{2}{|c|}{ Organically cultivated } & \multicolumn{2}{|c|}{$\begin{array}{c}\text { Fertilized treatments } \\
\text { in fertilization } \\
\text { experiment }\end{array}$} & \multirow[t]{2}{*}{$\begin{array}{l}\text { Difference } \\
\text { between } \\
\text { means, } \%\end{array}$} \\
\hline & Mean & Range & Mean & Range & \\
\hline Yield, $\mathrm{kg} / 16$ row metres & 35.1 & $33.1-37.0$ & 41.2 & $38.5-45.3$ & -24 \\
\hline Root dry matter content, $\%$ & 10.1 & $9.6-10.5$ & 10.5 & $10.3-10.8$ & -4 \\
\hline Carotene, $\mathrm{mg} / 100 \mathrm{~g} \mathrm{FW}$ & 6.62 & $6.22-7.02$ & 6.15 & $5.71-6.53$ & +8 \\
\hline $\mathrm{NO}_{3}-\mathrm{N}, \mathrm{g} / \mathrm{kg} \mathrm{DM}$ & 1.20 & $1.05-1.35$ & 1.34 & $1.14-1.56$ & -10 \\
\hline $\mathrm{N}, \%$ in $\mathrm{DM}$ & 0.96 & $0.91-1.00$ & 1.11 & $0.96-1.24$ & -14 \\
\hline $\mathrm{P}, \%$ in $\mathrm{DM}$ & 0.29 & $0.26-0.33$ & 0.22 & $0.20-0.25$ & +32 \\
\hline $\mathrm{K}, \%$ in $\mathrm{DM}$ & 2.74 & $2.42-3.05$ & 3.09 & $2.88-3.26$ & -11 \\
\hline $\mathrm{Ca}, \%$ in $\mathrm{DM}$ & 0.26 & $0.23-0.28$ & 0.30 & $0.29-0.30$ & -13 \\
\hline $\mathrm{Mg}, \%$ in $\mathrm{DM}$ & 0.12 & $0.11-0.13$ & 0.10 & $0.09-0.11$ & +20 \\
\hline Ash, $\%$ in DM & 7.8 & $7.0-8.5$ & 8.1 & $7.3-9.1$ & -4 \\
\hline Dietary fibre, $\%$ in DM & 3.7 & $3.3-4.0$ & 3.5 & $3.2-3.8$ & +6 \\
\hline Glucose, $\%$ in FW & 1.55 & $1.5-1.5$ & 1.35 & $1.2-1.5$ & \\
\hline Fructose, $\%$ in FW & 1.20 & $1.2-1.2$ & 1.20 & $1.1-1.3$ & \pm 0 \\
\hline Sucrose, $\%$ in FW & 4.10 & $3.9-4.3$ & 4.10 & $3.7-4.4$ & \pm 0 \\
\hline Total sugars, $\%$ in $\mathrm{FW}$ & 6.80 & $6.6-7.0$ & 6.65 & $6.5-7.0$ & +2 \\
\hline Taste scores & 6.9 & $6.9-7.0$ & 8.1 & $7.4-8.3$ & -15 \\
\hline Texture scores & 8.3 & $8.2-8.5$ & 8.1 & $7.5-8.6$ & +3 \\
\hline
\end{tabular}

FW $=$ fresh weight

$\mathrm{DM}=$ dry matter

Scores $=$ nine-degree Karlsruhe quality scale $(9$ excellent, 8 very good, 7 good, 6 satisfactory, 5 mediocre, 4 acceptable, 3 poor, 2 very poor, 1 unacceptable) 
Table 7. Comparison of measured yield and quality parameters for organically and conventionally cultivated carrots after storage.

\begin{tabular}{|c|c|c|c|c|c|}
\hline \multirow[t]{2}{*}{ After storage } & \multicolumn{2}{|c|}{ Organically cultivated } & \multicolumn{2}{|c|}{$\begin{array}{l}\text { Fertilized treatments } \\
\text { in fertilization } \\
\text { experiment }\end{array}$} & \multirow[t]{2}{*}{$\begin{array}{c}\text { Difference } \\
\text { between } \\
\text { means, \% }\end{array}$} \\
\hline & Mean & Range & Mean & Range & \\
\hline $\begin{array}{l}\text { Marketable yield, } \% \text { of } \\
\text { stored amount }\end{array}$ & 86.2 & $86.0-86.4$ & 58.5 & $54.2-63.1$ & +47 \\
\hline Weight loss, $\%$ & 13.9 & $13.7-14.0$ & 17.3 & $15.2-23.0$ & -20 \\
\hline Root dry matter content, $\%$ & 10.4 & $10.2-10.6$ & 11.1 & $10.9-11.3$ & -6 \\
\hline Carotene, $\mathrm{mg} / 100 \mathrm{~g} \mathrm{FW}$ & 5.26 & $4.62-5.90$ & 4.56 & $4.22-4.97$ & +15 \\
\hline $\mathrm{NO}_{3}-\mathrm{N}, \mathrm{g} / \mathrm{kg} \mathrm{DM}$ & 1.24 & $1.18-1.29$ & 1.44 & $1.28-1.58$ & -14 \\
\hline $\mathrm{N}, \%$ in DM & 0.91 & $0.86-0.95$ & 1.27 & $1.14-1.35$ & -28 \\
\hline $\mathrm{P}, \%$ in $\mathrm{DM}$ & 0.30 & $0.28-0.33$ & 0.25 & $0.23-0.27$ & +20 \\
\hline $\mathrm{K}, \%$ in DM & 3.02 & $2.75-3.28$ & 3.44 & $3.25-3.80$ & -12 \\
\hline $\mathrm{Ca}, \%$ in $\mathrm{DM}$ & 0.27 & $0.25-0.29$ & 0.33 & $0.32-0.35$ & -18 \\
\hline $\mathrm{Mg}, \%$ in $\mathrm{DM}$ & 0.13 & $0.13-0.14$ & 0.11 & $0.11-0.12$ & +18 \\
\hline Ash, $\%$ in DM & 7.2 & $7.0-7.4$ & 7.3 & $7.1-7.6$ & -1 \\
\hline Glucose, $\%$ in FW & 2.80 & $2.6-2.9$ & 2.20 & $2.0-2.4$ & +27 \\
\hline Fructose, $\%$ in FW & 2.20 & $2.1-2.4$ & 1.90 & $1.7-2.0$ & +16 \\
\hline Sucrose, $\%$ in FW & 2.40 & $2.0-2.8$ & 3.45 & $3.2-4.0$ & -30 \\
\hline Total sugars, $\%$ in FW & 7.40 & $7.3-7.6$ & 7.55 & $7.3-7.9$ & -2 \\
\hline Taste scores & 7.6 & $7.1-8.1$ & 6.1 & $5.5-6.7$ & +25 \\
\hline Texture scores & 7.4 & $7.2-7.6$ & 6.3 & $6.0-6.7$ & +18 \\
\hline
\end{tabular}

$\mathrm{FW}=$ fresh weight

$\mathrm{DM}=$ dry matter

Scores $=$ nine-degree Karlsruhe quality scale $(9$ excellent, 8 very good, 7 good, 6 satisfactory, 5 mediocre, 4 accept able, 3 poor, 2 very poor, 1 unacceptable)

After storage, the organically cultivated car- these two groups were compared (Table 7). rots still had higher carotene, $\mathrm{P}, \mathrm{Mg}$ and glu- The weight loss during storage, the root dry cose contents, but also the marketable yield, matter content, and the $\mathrm{NO}_{3}-\mathrm{N}, \mathrm{N}, \mathrm{K}, \mathrm{Ca}$ fructose content, taste and texture scores were higher than in the fertilized treatments in the and sucrose contents were lower in the organfertilization experiment when the means of ically cultivated carrots than in the fertilized treatments in the fertilization experiment. 


\section{DISCUSSION}

\subsection{Growth and quality criteria influenced by fertilization practices}

\subsubsection{Placement fertilization}

In vegetable growing, the most common fertilization practice still is broadcast fertilization, although placement fertilization has been shown to improve the yields of many crops (COOKE et al. 1956, VARIS and LANNETTA 1974, LyNGSTAD 1977, MulKey et al. 1979, EKeberg 1986). The placement method also increases the efficiency of nitrogen (AURA 1967, LyNGSTAD 1977), phosphorus (MACLEOD et al. 1975, Fox and KANG 1978, Mulkey et al. 1979, Pearson and Kirkham 1980, Peterson et al. 1981) and potassium (PARKS and WAlKer 1969).

The possible reasons for the fact that broadcast fertilization is still used are the low price of fertilizers and the lack of proper fertilizer drills for vegetable crops. In the present study it was shown that it is possible also in carrot cultivation to increase yields by placement of NPK or PK fertilizer. The nutrient level used in the present experiment was chosen according to the practice in Finnish carrot production, but because the placement fertilization has been shown to increase also the fertilizer efficiency, the difference in carrot yields between placement method and other application methods would probably have been even bigger if a lower nutrient level had been used. It would be worth while to study the lowest effective fertilizer levels for the placement method that would achieve yields similar to those of the inefficient application methods. From the ecological point of view, too, this would be an interesting topic. Nitrogen, in particular, is a nutrient which is easily leached by rain or irrigation (WATTS 1975).

The placement of $\mathrm{P}$ and $\mathrm{K}$ increased also the root dry matter, $\mathrm{N}$ and $\mathrm{P}$ contents. Recently, BENDER et al. (1986) have reported interesting results that in carrot plants optimally supplied with phosphorus, the growth, phosphorus concentration in the tap root, photosynthetic $\mathrm{CO}_{2}$ fixation and assimilate translocation were considerably increased in comparison to the low phosphorus treatment. Further, they concluded that inadequate phosphorus nutrition of carrot plants results in suppressed development of the shoot and the tap root. At least as far as root development is concerned, this suppression may be partly related to a reduced cytokinin concentration, which may in turn restrict the meristematic activity in the root. Also according to Hole et al. (1983), the rate of cell division and cell expansion might influence the sink activity.

The results of yield dry matter and $\mathrm{P}$ content obtained in the present study are in good agreement with those of BENDER et al. (1986). The placement of phosphorus and potassium has increased the yield, phosphorus concentration in root in 1986, photosynthetic $\mathrm{CO}_{2}$ fixation (yield, correlation between root and shoot dry weights) and assimilate translocation (dry matter content and correlation between dry matter and sucrose as well as total sugars). Thus, a disadvantage of the broadcast method and the NPK fertirrigation method is hypothesized to be an impaired efficiency of phosphorus, an effect which is considerable when the soil phosphorus content is low, as was the case in the present field experiments.

Placement of phosphorus has been reported to be most effective in soils with low phosphorus levels (Fox and KANG 1978, PETERSON et al. 1981), in dry soil conditions (CHAUD- 
hary and Prihar 1974, Ekeberg 1986), and at low soil temperatures (GINGRICH 1964, Power et al. 1964).

In the present study, no difference in carrot root $\mathrm{P}$ content was found between the placement of NPK and PK fertilizer. In many other studies (SoON and Miller 1977, Steele and Saunders 1980, Leikam et al. 1983, SanGAKKARA and Сно 1987), better uptake and utilization of $\mathrm{P}$ by crops have been found when $\mathrm{NH}_{4}-\mathrm{N}$ compounds were present in $\mathrm{P}$ fertilizer or were applied with it. In the present study, the root $\mathrm{P}$ content correlated positively with the root $\mathrm{N}$ content in both years $\left(\mathrm{r}=0.815^{*}\right.$ in $1985, \mathrm{r}=0.391 *$ in 1986$)$, which indicates that there might be some interaction between uptake of these two nutrients. According to the results of the present study, it is impossible to hypothesize whether $\mathrm{P}$ has stimulated root growth and increased $\mathrm{N}$ uptake, whether $\mathrm{N}$ has increased root proliferation or the metabolic activity of the plant, and has thus increased absorbtion, or whether some other causes have had an effect.

The $\mathrm{NO}_{3}-\mathrm{N}$ content of carrot roots was also favourably influenced by placement fertilization. NPK fertirrigations had a negative effect, because it increased the $\mathrm{NO}_{3}-\mathrm{N}$ content in carrot roots. Although all measured $\mathrm{NO}_{3}-\mathrm{N}$ levels were relatively low, and carrot is not typically a species that accumulates $\mathrm{NO}_{3}-\mathrm{N}$, this result is interesting. The effects of genotype, climate and nitrogen fertilizer amounts on the $\mathrm{NO}_{3}-\mathrm{N}$ content of vegetables are extensively documented, but only few reports are available on the effects of fertilizer application methods on the $\mathrm{NO}_{3}-\mathrm{N}$ content of vegetables. In the study of BAKKER et al. (1984) on lettuce (Lactuca sativa L.), nitrogen fertirrigations led to higher $\mathrm{NO}_{3}-\mathrm{N}$ contents in the crop than did broadcast fertilization. They also found a relatively high $\mathrm{N}$ recovery percentage in the fertirrigated crop, especially at a low level of $\mathrm{N}$ fertilization. The proportion of $\mathrm{NO}_{3}-\mathrm{N}$ in the total $\mathrm{N}$ content was higher in the fertirrigated crops as compared to broadcast fertilization. Thus the fertirriga- tion method had advantages (high $\mathrm{N}$ recovery percentage) and disadvantages (high proportion of $\mathrm{NO}_{3}-\mathrm{N}$ to total-N). According to the results of the present investigation, the $\mathrm{NO}_{3}-\mathrm{N}$ content in carrot is a quality criterion that can be positively affected by placement fertilization.

In future research it would be important to study further the influences of different fertilization practices on the vegetable $\mathrm{NO}_{3}-\mathrm{N}$ contents, especially with plant species that accumulate high amounts of $\mathrm{NO}_{3}-\mathrm{N}$.

The placement application method did not show only positive effects, since indicative results showed that placement of fertilizer impaired the taste of carrot as compared to NPK fertirrigations, but not as compared to broadcast fertilization. However, the differences were small.

In conclusion, as the placement of fertilizer has proved to have positive effects on yield, root dry matter content, $\mathrm{NO}_{3}-\mathrm{N}, \mathrm{N}$ and $\mathrm{P}$ contents, and on carotene content in less favourable weather conditions, this fertilizer application method should be studied further and should also be applied to commercial vegetable production. Especially the placement of $\mathrm{P}$ and $\mathrm{K}$ was important.

\subsubsection{Single vs. split application}

In the preliminary results of the present study it was shown that ash and dietary fibre contents in carrots were increased by single application as compared to split applications. Ash and dietary fibre were the only quality criteria which were affected by the single vs. split application procedure.

Although ash does not contain nitrogen, it contains all other nutrients which the plant has taken up, and thus it represents the intensity of nutrient uptake. Consequently, it is natural that the ash content correlates with the shoot and root $\mathrm{N}$ and $\mathrm{K}$ contents, as mentioned in the Results, as $\mathrm{N}$ and $\mathrm{K}$ are, in fact, the most abundant nutrients in carrots (VARO et al. 1980, III/Table 2). An interesting observation was the negative correlations be- 
tween both the shoot and the root Ca contents and the root ash content. This might be due to cation antagonism. As to carbohydrates, the ash correlated positively with the dietary fibre content, but negatively with the total sugar and root dry matter contents. Thus it can be hypothesized that a good nutrient supply makes it possible to process the photosynthates into more complicated compounds, but if the nutrient supply is insufficient, a greater amount of photosynthates remains as sugars.

There is, for the present, little literature concerning the effects of growing practices or fertilization on the dietary fibre contents of vegetables. HABBEN (1972) found that an increasing nitrogen amount decreased the raw fibre content of carrot, whereas an increasing potassium fertilization increased the raw fibre content of carrot, but the influences were relatively small. ROBERTSON et al. (1980) found that the water holding capacity of carrot fibre does not appear to be influenced by the variety or age of carrot. The older the carrot, the greater is the cation exchange capacity of carrot fibre, but variety differences are not important. Horvath-Mosonyl et al. (1983) reported that, for carrots of the same variety and age, the mass or size of the carrot does not influence the dietary fibre content. In white cabbage, NygaArd Sørensen (1984) found that increasing the nitrogen fertilization decreased the dietary fibre content, whereas increasing the phosphorus application showed a slight tendency to increase the dietary fibre content. Potassium, on the other hand, had no effect on the dietary fibre.

After cereal products, vegetables and fruits are the main sources of dietary fibre in the Finnish diet (VARO et al. 1984). The importance of dietary fibre in food for human consumption is now recognized. Low dietary fibre intake predisposes the individual to the development of several lifestyle-related diseases (Spiller and Freeman 1981). A significant proportion of the dry matter content of carrots is made up of dietary fibre, i.e. the part of the plant which cannot be hydrolysed by the human digestive enzymes, and which con- sists mainly of the cellulose, hemicellulose, lignin and pectin compounds found in cell walls. The important physiochemical properties for human intestinal activity are the water-binding capacity of hydrophilic polysaccharides, the cation exchange ability of certain acidic polysaccharides and the bile salt adsorption ability of lignin and the pectins (SPILLER and AMEN 1975). The role of carrots in the diet is associated with the advantageous composition of its dietary fibre content, a large proportion of which is pectin, giving it an excellent waterbinding capacity (Horvath-Mosony et al. 1983). Because the placement fertilization practice has shown other positive effects on growth and quality, future research should concentrate on the placement application method when single application is used.

\subsubsection{Fertirrigation}

Fertirrigation did not prove to be a good fertilization practice in the environmental conditions of the present experiment, as far as yield, root dry matter content, $\mathrm{NO}_{3}-\mathrm{N}, \mathrm{N}, \mathrm{P}$, ash and dietary fibre contents are concerned. The only quality criterion where fertirrigation gave better results than placement fertilization was taste.

Because no earlier studies could be found on the effects of fertilization practices on carrot taste, and because the results of the present study should be considered to be indicative only (IV), the possible reasons for differences in carrot taste should be discussed later, after new experiments. In a review, SIMON (1985) claims that variation in cultural practices and environment has less effect on carrot flavour than genetic variation, but more radical treatments could be tested, e.g. reduction in the availability of water or fertilizer late in the growing season might increase the sugar content without decreasing yield or shelflife.

There are probably several reasons why fertirrigation turned out to be a less beneficial fertilization practice than placement fertilization. First, as hypothesized earlier, the effi- 
ciency of phosphorus may be impaired. Secondly, the soil was wet throughout the growing period in both years (except June 1986) by precipitation, and thus the water given by fertirrigation was not necessary for the plants. One disadvantage of fertirrigation is thus that fertilizer application is dependent on water application. On the other hand, fertirrigation of nitrogen has shown good efficiency of nitrogen (WATTS 1975, BAKKER et al. 1984), which is important. Thus in the future the PK placement in spring followed by $\mathrm{N}$ fertirrigations during the growing period could be a good fertilization practice, combining the advantages of different fertilizer application methods.

\subsection{Quality criteria not or only slightly influenced by fertilization practices}

\subsubsection{Carotene}

Earlier studies have confirmed that the carrot carotene content is influenced by genotype (Gabelman 1974, Simon and WolfF 1987), environment (BARNES 1936, BANGA et al. 1955, HabBen 1972, Simon et al. 1982, SimON and WolfF 1987) and by the size and age of carrot (BARNES 1936, BANGA et al. 1963, BANGA and De Bruyn 1964, HabBen 1972, Phan and Hsu 1973).

BANGA and DE BRUYN (1964) have published the following summary of the carotenogenesis in carrot root. In a carrot, the enlargement of the root and the ripening proceeds simultaneously. Different conditions may favour one activity more than the other. As the root grows, its carotenoid concentration gradually increases up to a certain maximum. This is caused by the increase in the carotenoid content in the individual cells of the ripening tissue, but also by the increase in the ripe upper part of the root. The carotenoid contents of carrot roots should therefore be determined in relation to the size of the root. The carotenoid content that can be reached depends primarily on adequate photosynthesis. If the roots are grown in a well-drained soil of good texture, there are two types of growth conditions which may further modify the carotenoid content in relation to root weight. These are the factors that control the growth rate (plant density, soil moisture content, nutrient supply) and, secondly, temperature. When the temperature is high, ripening is favoured; when the temperature is low, primary vegetative growth is favoured.

Thus the results of the present study are in good agreement with the above literature. The carotene content was $41 \%$ higher in the favourable year 1986 (II/Fig. 1), and the yield was $42 \%$ higher in 1986 than in 1985 (I). Thus a good growth rate and favourable weather conditions (I) increased the carotene contents, as did the ripening of the carrots when they grew bigger and older (II/Fig. 2).

The average carotene content at harvest in unfertilized treatments was $3.7 \mathrm{mg} / 100 \mathrm{~g}$ fresh weight in 1985 and $5.8 \mathrm{mg} / 100 \mathrm{~g}$ fresh weight in 1986. The fertilization increased the carotene contents by $21 \%$ and $7 \%$, respectively. The increases are notable but not statistically significant. The reason for this may be due to uneven experimental fields or uneven plant material. The experiment was arranged according to the method of completely randomized blocks, because it was known that the field was not completely uniform (I/Table 4). The added area of plots was $1,000 \mathrm{~m}^{2}$ and the total area with rows included was nearly $2,000 \mathrm{~m}^{2}$. It was difficult to find a uniform experimental field of this size.

The single grouping of the completely randomized block design did not help the situation enough, as the standard deviations within treatments were moderate. The reason for this may be uneven soil conditions within the blocks or uneven plant material. The used determination method was tested, and the repetitions were exact. Carrots of similar size were used for the determinations. In field experiments like this, where variation in the measured constituent depends partly on genotype (Gabelman 1974, Simon and WolfF 1987), it would be a great advantage to have a clonal plant material or at least an $F_{1}$ hybrid variety. Somaclonal artificial seeds will be of great 
help in future. The uniform plant material minimizes the genetic differences between individuals. In the present study, cv. Nantes Duke Notabene $370 \mathrm{~Sv}$ was used. It is an outbreeding variety, and genetic differences between individuals may occur.

The reason for the observation in the present study that the placement of $\mathrm{P}$ and $\mathrm{K}$ increased the carotene content in the less favourable year 1985 might be that the placement of $\mathrm{P}$ and $\mathrm{K}$ had improved the early root growth or promoted the early uptake of phosphorus. In that case, carrots might be riper at harvest. However, this hypothesis is not supported by the root dry weights (I/Fig. 2) or phosphorus contents (III/Fig. 2d) studied on the first sampling date in 1985. The first sampling date was two months after sowing. At harvest the mean root fresh weight in treatments where $\mathrm{P}$ and $\mathrm{K}$ were placement fertilized was $86.4 \mathrm{~g}$, and $87.1 \mathrm{~g}$ in treatments where $\mathrm{P}$ and $\mathrm{K}$ were not placement fertilized. Thus the size of the roots cannot be the reason for a tendency for a higher carotene content in treatments where $\mathrm{P}$ and $\mathrm{K}$ were placement fertilized. The reason why the placement of $\mathrm{P}$ and $\mathrm{K}$ increased the carotene content in unfavourable weather conditions ought to be investigated further to determine the possible mechanisms behind this phenomenon.

The interest and importance of carrot in the diet have increased lately with increasing knowledge of the influence of carotenoids on human health. During the last decade, for example, epidemiologic studies have indicated that the incidence of cancer may be slightly lower among individuals with an above-average intake of $\beta$-carotene and other carotenoids (PETo et al. 1981); carotenoid pigments have antitumour activity and may hold promise for the prevention of light-induced skin tumours (MATHEws-Roth 1982); and some results provide a rationale for the possible anticancer activity of $\beta$-carotene, insofar as the onset and progress of cancer are affected by free radicals (BURTON and INGOLD 1984).

Within the United States - Finland Epidemiologic Studies of Nutrition and Can- cer project, HeinONEn (1988, personal communication) has calculated that vegetables provide $83 \%$ of the $\beta$-carotene intake among the Finnish population. Of this $83 \%$, carrots constitute $84 \%$. Vegetables provide $32 \%$ of the vitamin $\mathrm{A}$ intake if the diet does not include liver, if it does, vegetables provide 14 $\%$ of the vitamin A intake of the Finnish population. Thus the carotene content of carrot is of particular interest.

\subsubsection{Glucose, fructose and sucrose}

In the literature there are contradictory reports of the influence of fertilization on carrot sugar contents (IV). These contradictory results can be partly explained by genotypes, because it has been confirmed that genotype has a strong influence on carrot sugar contents as compared to the effect of climate or soil influences (SıMON et al. 1982). However, this does not explain the clear differences between years which have been observed in experiments where the same variety has been grown on the same soil in different years (HABBEN 1972, Nilsson 1979, IV).

The state of carbohydrates in plants is dynamic. There are various transformation reactions between different carbohydrates. Their degradation produces energy utilized in many of the synthetic reactions. Carbon skeletons produced as a result of the transformation and partial degradation of sugars are essential to the construction of proteins, lipids, etc. (DEvLIN 1975). This dynamic role of carbohydrates may explain the contradictory results in the literature of the influence of fertilization on the carrot sugar contents. The harvested plant is a result of all growth factors, and numerous interactions affect the growth, need for energy and synthesis of compounds in the plant. In different fertilization experiments in different years, these needs have differed, depending on all growth factors, not only fertilization.

Sugarbeet, Beta vulgaris L., is also a plant that accumulates sugars in its storage root. There is some discrepancy in the literature on 
the significance of the factors influencing the sugar content of the roots. It has been suggested that storage of sucrose could be considered a surplus production beyond the requirement for beet growth (UlRICH 1952, 1955), that root growth and sucrose storage are controlled by an internal mechanism determined by genotype (TERRY 1968), that the beet exerts a "pull" via the phloem on the assimilate production in the leaves (HABESHAw 1973), and that the capacity of the accumulating organ is correlated with growth (MILFORD 1973, Willenbrink 1982).

In the present study (IV) it was hypothesized that because more photosynthates had been produced in fertilized treatments and in the climatically more favourable year 1986 (I), a greater amount of photosynthates had been used for phytomass production and thus less sugars were left to be translocated into the storage cells. This hypothesis has a similar trend as mentioned above with the sugarbeet, e.g. the sugar content could be considered a surplus production beyond the plant's requirement, and that the capacity of an accumulating organ is correlated with growth (MILFORD 1973).

\subsubsection{Quality of stored carrots}

According to the results of the present investigation, the fertilization practices have no or only little effects on the quality of stored carrots. The genotype, environmental conditions during the growing period, and storage conditions are possibly much more important factors than the fertilization practice. The heavy infection of Mycocentrospora acerina (R. Hartig) Deighton may also be a reason why no significant differences were found.

In storage, however, the quality of carrot changes. Because, at harvest, no well-defined stage of biochemical maturity has been detected in carrots (NILSSON 1987), attempts have been made to minimize the metabolic activity by keeping the storage temperature at $\pm 0{ }^{\circ} \mathrm{C}$ and the relative humidity at $93-98 \quad \%$ (SAlunke and Desai 1984). However, changes in the constituents do occur for several reasons. 1) The loss of water decreases the weight of the product, and if some constituent is determined per fresh weight, its amount increases as the amount of water decreases. If the amount of some constituent is determined per dry weight, the loss of water does not affect its amount. 2) The metabolic activity causes loss of dry matter through respiration (Hasselbring 1927, Fritz et al. 1978). Irrespective of whether the amount of a certain constituent is determined per fresh or dry weight, its amount increases through this concentration effect. Further, it can be hypothesized that certain constituents can be 3 ) synthesized or 4) decomposed during storage, and thus their amount increases or decreases, respectively. All or some of the above mentioned reactions may occur simultaneously in stored vegetables.

\subsection{Organically cultivated carrots}

At harvest the higher carotene content in the organically cultivated carrots might be due to the fact that these carrots were three weeks older than those in the fertilization experiments, because they were sown already in May (Table 2). It is well documented that the carotene content of carrots increases as the carrots become bigger and older (BARNES 1936, Banga and De Bruyn 1964, Habben 1972). This was also the case in the present study (II/Fig. 2). However, the differences in carotene contents between the two organically cultivated locations were greater $(11 \%$ at harvest, $22 \%$ after storage) than the differences in the organically cultivated carrots and in carrots cultivated for the fertilization experiment. There was a considerable difference in the $\mathrm{P}$ contents in the two organically cultivated samples, and also a difference as compared to $\mathrm{P}$ content in the fertilization experiment. These differences were in relation to the soil $\mathrm{P}$ levels given in the original article I, Figure 5. The $\mathrm{Mg}$ contents were also in relation to the soil Mg levels (I).

At harvest, there were no differences in the 
fructose, sucrose and total sugar contents, but the glucose content was higher in the organically cultivated carrots than in the fertilized carrots of the fertilization experiment. As hypothesized in the original article IV, the sugar contents ought to be examined in relation to growth, and thus the higher glucose content might be explained by restricted growth in the organically cultivated plots. After storage, the sucrose content had decreased and simultaneously the glucose and fructose contents had increased more in the organically cultivated carrots than in the carrots grown in the fertilization experiment. The tendency for the sucrose content to decrease and the glucose and fructose contents to increase during storage is well known (BARNES 1936, SAlminen et al. 1970, Nilsson 1979), but the reason for the much greater changes in the organically cultivated carrots remained unknown.

At harvest, the organically cultivated plots produced lower yields, but after storage the marketable yield was much greater than that of the fertilization experiment. The main reason for the much better storage ability was the absence of Mycocentrospora acerina (R. Hartig) Deighton, a soilborne disease, which spoiled a large amount of carrots in the fertilization experiment.
The mean $\mathrm{NO}_{3}-\mathrm{N}$ contents were lower in the organically cultivated carrots at harvest and after storage, but when the ranges are examined, it can be seen that some fertilization treatments also produced carrots with low $\mathrm{NO}_{3}-\mathrm{N}$ contents (Tables 6 and 7). The reasons for the lower $\mathrm{N}, \mathrm{K}$ and $\mathrm{Ca}$ contents in the organically cultivated plots remain uncertain, because the values of these nutrients in the soil samples were equal or higher to those in the fertilization experiment (I/Fig. 5). Also the amounts of nutrients given by fertilization in spring were greater in the organically cultivated fields (I/Tables 1 and 2). For some reason, the uptake of these nutrients was diminished.

The taste of the organically cultivated carrots was poor at harvest, but after storage they received the best taste scores. The tasters explained the poor taste at harvest as follows: resembles soap or perfume, the carrots are bitter or harsh. Because the aroma compounds were not determined in this investigation, it is not possible to identify the compound responsible for this unfavourable taste. In any case, the compound was decomposed during storage, because the tasters no longer recognised it after storage. 


\section{SUMMARY AND CONCLUSIONS}

The quality of vegetables is influenced by genotype, environment, growing practices, harvest, storage and marketing. The literature contains only few investigations concerning different fertilization practices in carrot cultivation. Most investigations of carrot fertilization deal with the effects of increasing amounts of nutrients on carrot yield and some quality criteria. These results are partly contradictory. However, in future, for economical, marketing, and environmental reasons there is a need to develop fertilization practices to increase the fertilizer efficiency, to increase the uniform quality of vegetable products, and to minimize the environmental disadvantages of fertilizer use. Thus the present study examined the influences of different fertilization practices on the carrot yield and quality, mainly the inner quality. The main results and conclusions were as follows:

1. The fertilization practices affected the carrot yield and the root dry matter content. The placement of NPK or PK fertilizer increased the carrot yield as compared to the broadcast or fertirrigation methods, and the rout dry matter content was increased by $\mathrm{PK}$ placement with $\mathrm{N}$ fertirrigations as compared to NPK fertirrigations. High carrot yields were obtained when the total phytomass production was high, as the root and shoot dry weights were positively correlated.

The results of yield and root dry matter content are in good agreement with recent studies. Thus the disadvantage of broadcast fertilization and NPK fertirrigations is hypothesized to be an impaired efficiency of phosphorus, which is considerable when the soil phosphorus content is low.

2. The effects of different fertilization prac- tices on the carrot carotene contents were slight. In the climatically less favourable year 1985, the placement of PK fertilizer had a tendency to yield a higher carotene content than did the broadcast or NPK fertirrigation methods. In the climatically more favourable year 1986, fertilization practices had no effect on the carrot carotene content.

In all treatments, the carotene content increased as the growing season progressed and the carrots became larger and older. All treatments considered, the carotene content was $41 \%$ higher in the climatically more favourable year 1986 than in 1985 . According to the literature, the carrot carotene content is strongly influenced by genotype, climate and the size and age of carrots; thus it is logical that the effects of fertilization practices were slight, though they may be important in unfavourable growing conditions.

3. The present study shows that it is possible to influence the $\mathrm{NO}_{3}-\mathrm{N}$ content of carrots by developing the fertilization practices. This is an important finding, because it is undesirable to have high $\mathrm{NO}_{3}-\mathrm{N}$ contents in vegetables used for human nutrition. Low $\mathrm{NO}_{3}-\mathrm{N}$ contents were found in the unirrigated placement fertilized treatments, and the highest $\mathrm{NO}_{3}-\mathrm{N}$ contents were found in NPK fertirrigations without basic fertilization. Irrigation increased the $\mathrm{NO}_{3}-\mathrm{N}$ content in carrots, but the results show that the placement of $\mathrm{P}$ and $\mathrm{K}$ as such had a positive effect on the carrot $\mathrm{NO}_{3}-\mathrm{N}$ content, lowering it.

In future research it would be important to study further the influences of different fertilization practices on vegetable $\mathrm{NO}_{3}-\mathrm{N}$ contents, especially with plant species that accumulate high amounts of $\mathrm{NO}_{3}-\mathrm{N}$. 
4. In 1986, the placement of NPK or PK fertilizer increased the carrot $\mathrm{N}$ and $\mathrm{P}$ contents as compared to NPK fertirrigations without basic fertilization, but the fertilization practices had no effects on the $\mathrm{K}$, $\mathrm{Ca}$ and $\mathrm{Mg}$ contents. Because the preliminary results for 1985 were partly contradictory, these results should be regarded as indicative only. The increased $\mathrm{N}$ and $\mathrm{P}$ contents in carrots are not directly important quality criteria in vegetables used for human nutrition, but they indicate an increased intensity of nutrient uptake. The results of the present investigation show that the placement of NPK or PK fertilizer had positive effects on the yield, dry matter content, carotene content in unfavourable growing conditions, and on the $\mathrm{NO}_{3}$ $\mathrm{N}$ content. Thus the increased $\mathrm{N}$ and $\mathrm{P}$ contents may have had indirect positive effects on the quality of carrot.

5. The single application increased the ash and dietary fibre contents of carrots as compared to split applications. These promising preliminary results should be verified in future studies, as ash and dietary fibre were determined only in 1986, and only few reports could be found in the literature, although the importance of dietary fibre in human nutrition is evident.

6. The fertilization practices had no effects on the carrot glucose, fructose or sucrose contents either in 1985 or in 1986 . The glucose, fructose and total sugar contents were higher in the climatically less favourable year 1985 than in 1986, whereas the sucrose content showed mainly an opposite trend, being higher in 1986 than in 1985. In 1986, the unfertilized treatments yielded a higher total sugar content than did the fertilized treatments. These results, together with yield results, led to the hypothesis that the sugar content of carrot is related to growth. In the favourable year and in fertilized treatments, greater amounts of photosynthates were produced, but they were used for growth and thus less sugars were left for the storage organ. An adequate sugar content is important for the taste of carrot, because sugars contribute to the sweetness. Thus, in future studies, the carrot sugar contents should be investigated comprehensively, in relation to yield and other energy or carbon consuming processes which can use sugars to produce other quality criteria.

7. The indicative results for taste and texture showed that the NPK fertirrigations without basic fertilization had a slight positive effect on carrot taste and texture as compared to placement fertilization. In future studies, the role of irrigation, fertirrigation and placement fertilization in carrot taste and texture should be investigated, because very little literature on this subject is available.

8. The fertilization practices had only slight effects on the storage ability of carrots. In both years, the NPK fertirrigations without basic fertilization showed a tendency to produce lower marketable yield after storage than did single application.

9. At harvest, the ranges of many quality criteria between the two organically cultivated materials were greater than the differences between the means for the two cultivation methods (organically cultivated carrots vs. carrots grown in the fertilized treatments in the fertilization experiment). At harvest, the organically cultivated material had lower yield and $\mathrm{N}$ content, and worse taste, but higher $\mathrm{P}$ and $\mathrm{Mg}$ contents than the carrots grown in the fertilized treatments of the fertilization experiment. The organically cultivated carrots stored well because of the absence of the soilborne disease, Mycocentrospora acerina (R. Hartig) Deighton. After storage they had higher marketable yield, less weight loss, a lower $\mathrm{NO}_{3}-\mathrm{N}$ content, higher $\mathrm{P}, \mathrm{Mg}$, glucose and fructose contents, better taste and better texture than did the carrots grown in the fertilized treatments of the fertilization experiment. On the other hand, the organically cultivated carrots had lower dry matter, $\mathrm{N}$ and $\mathrm{Ca}$ contents than 
did the carrots grown in the fertilized treatments of the fertilization experiment.

In conclusion, the fertilization practices affected carrot yield, dry matter, $\mathrm{NO}_{3}-\mathrm{N}$, $\mathrm{N}$ and $\mathrm{P}$, ash and dietary fibre contents. On the other hand, the fertilization practices had no, or only slight, effects on the carotene and sugar contents, taste, texture and storage ability. So far, in horticultural and agricultural fertilization studies, at- tention has been paid to yield quantity. In future, the high yield demand should not take priority over quality. The results of the present investigation do, however, show that high yield and quality, as far as dry matter, carotene, $\mathrm{NO}_{3}-\mathrm{N}, \mathrm{N}, \mathrm{P}, \mathrm{K}$, $\mathrm{Ca}, \mathrm{Mg}$, ash and dietary fibre are concerned, are not contradictory, but convergent. 


\section{REFERENCES}

Alabran, D.M. \& Mabrouk, A.F. 1973. Carrot flavor, sugars and free nitrogenous compounds in fresh carrots. J. Agric. Food Chem. 21: 205-208.

Aura, E. 1967. Effect of the placement of fertilizer on the development of spring wheat. J. Scient. Agric Soc. Finl. 39: 148-155.

- 1983. Kastelulannoitus, tutkimisen arvoinen lannoitusmenetelmä. Käytännön maamies 12: 12-14.

- 1985. Avomaan vihannesten veden ja typen tarve. Maatalouden tutkimuskeskus. Tiedote 7: 1-61. [Nitrogen and water requirements for carrot, beetroot, onion and cabbage. Communications of Agric. Res. Centre, Jokioinen.]

Bakker, M.J., Sl.angen, J.H.G. \& Gl.as, W. 1984. Comparative investigation into the effect of fertigation and of broadcast fertilization on the yield and nitrate content of lettuce (Lactuca sativa L.). Neth. J. Agric. Sci. 32: $330-333$.

Banga, O., De Bruyn, J.W. \& Smeets, L. 1955. Selection of carrots for carotene content. II. Subnormal content at low temperature. Euphytica 4: 183-189.

-, \& De Bruyn, J.W. 1964. Carotenogenesis in carrot roots. Neth. J. Agric. Sci. 12: 204-220.

-, De Bruyn, J.W., Van Bennekom, J.L. \& Van Keulen. H.A. 1963. Selection of carrots for carotene content. $\mathrm{V}$. The effect of the soil moisture content. Euphytica 12: $137-146$.

BARNES, W.C. 1936. Effects of some environmental factors on growth and color of carrots. Cornell Univ. Agric. Exp. Sta. Mem. 186: 1-36.

Bendér, L., Stiebeling, B. \& Neumann, K.-H. 1986. Investigations on photosynthesis and assimilate translocation in Daucus carota $\mathrm{L}$. as influenced by a varied phosphorus supply and changes in the endogenous hormonal system following $\mathrm{GA}_{3}$ treatments. $\mathrm{Z}$. Pflanzenernaehr. Bodenk. 149: 533-540.

Bishop, R.F., Chipman, E.W. \& Mac Eachern, C.R. 1973. Effect of nitrogen, phosphorus and potassium on yield and nutrient levels in carrots grown on sphagnum peat and mineral soils. Comm. Soil. Sci. Pl. Anal. 4: 455-474.

Burton, G.W. \& Ingol.d, K.U. 1984. B-carotene: An unusual type of lipid antioxidant. Science 244: 569-573.

Chaudhary, M.R. \& Prihar, S.S. 1974. Comparison of banded and broadcast fertilizer applications in relation to compaction and irrigation in maize and wheat. Agron. J. 66: 560-564

Cooke, G.W., Jackson, M.W., Widdowson, F.V., WIL.
Cox, J.C. \& Goodway, N.D. 1956. Fertilizer placement for horticultural crops. J. Agric. Sci. 47: $249-255$.

Devlin, R.M. 1975. Plant physiology. 600 p. 3rd Ed. New York.

Dıоuнy, J. 1981. Alternativa odlingsformer - Vãxtprodukters kvalitet vid konventionell och biodynamisk odling. Inst. Växtodl. Rapp. 91: 4-143.

Dragland, S. 1978. Nitrogen- og vassbehov hos gulrot. Forskn. Förs. Landbr. 29: 139-159.

Ekeberg, E. 1986. Radgjödsling på myr. Forskn. Förs. Landbr. 37: 23-28.

Engelstad, O.P. \& Terman, G.L. 1980. Agronomic effectiveness of phosphate fertilizers. In: "The role of phosphorus in agriculture", (Eds. F.E. KHASAWNEH, E.C. Sample \& E.J. Kamprath), p. 311-329.

Esal.a, M. \& LARPES, G. 1986a. Effect of the placement technique and amount of fertilizer on spring wheat and barley grown on clay soils. I. Effect on grain yield. Ann. Agric. Fenn. 25: 159-167.

—, \& LARPes, G. 1986b. II. Effect on the quality and mineral contents of grain yield. Ann. Agric. Fenn. 25: $169-175$.

Fox, R.L. \& KANG, B.T. 1978. Influence of phosphorus fertilizer placement and fertilization rate on maize nutrition. Soil Sci. 125: 34-40.

Freeman, J.A. \& Harris, G.H. 1951. The effect of nitrogen, phosphorus, potassium and chlorine on the carotene content of the carrot. Sci. Agric. 31: 207-211.

Freeman, R.E. \& Simon, P.W. 1983. Evidence for simple genetic control of sugar type in carrot (Daucus carota L.). J. Amer. Soc. Sci. 108: 50-54.

Fritz, D., Káppel, R. \& Weichmann, J. 1978. Einfluß des Anbaues auf Lagereignung und Lagerverhalten von Obst und Gemüse. Ernähr.-Umschau 25: 78-84.

Gabelman, W.H. 1974. The prospects for genetic engineering to improve nutritional values. Nutrition qualities of fresh fruits and vegetables. (Eds. P. White \& N. Selwey). p. 147-155. New York.

Gallagher, P.A. 1966. The effect of potassium on yield and quality of carrots. Proc. 8. Intern. Potash Inst. Congr. p. 257-263. Brüssel.

Gingrich, J.R. 1964. Relationship of soil temperature, water soluble $\mathrm{P}$ in applied fertilizer and method of placement to growth of winter wheat. Agron. J. 56: $529-532$.

Gregersen, A. 1978. Tilførsel af kunstgødning. Nord. Jordbr. Forskn. 60: 77-78. 
Habвen, J. 1972. Einfluss von Düngung und Standort auf die Bildung wertgebender Inhaltstoffe in Möhren (Daucus carota L.). Diss. Techn. Univ. München.

Habeshaw, D. 1973. Translocation and the control of photosynthesis in sugar beet. Planta 110: 213-226.

HANSEN, H. 1981. Comparison of chemical composition and taste of biodynamically and conventionally grown vegetables. Qual. Plant. Pl. Foods Hum. Nutr. 30: 203-211.

Hasselbring, H. 1927. Carbohydrate transformation in carrots during storage. PI. Physiol. 2: 225-243.

Hole, C.C., Barnes, A., Thomas, T.H., Scott, P.A. \& RANKIN, W.E. 1983. Dry matter distribution between the shoot and storage root of carrot (Daucus carota L.). Ann. Bot. 51: 175-187.

Horvath-Mosonyı, M., Rıgo, J. \& Hegedos-Volggyesı, E. 1983. Study of dietary fibre content and fibre components of carrots. Acta Alimentaria 12: 199-210.

KaIla, A. \& Hänninen, P. 1961. Fertilizer nitrogen in soil. J. Scient. Agric. Soc. Finl. 33: 167-184.

KÄhÁRı, J. \& Elonen, P. 1969. Effect of placement of fertilizer and sprinkler irrigation on the development of spring cereals on the basis of root investigations. J. Scient. Agric. Soc. Finl. 41: 89-104.

Lehtinen, S. 1984. Avomaavihannesten lannoitus- ja kastelukokeet 1978-1983. Maatalouden tutkimuskeskus. Tiedote 21: 1-62. [Fertilization and irrigation experiments for open field vegetables. Communications of Agric. Res. Centre, Jokioinen.]

Leikam, D.F., Murphy, L.S., Kissel, D.E., Whitney, D.A. \& Moser, H.C. 1983. Effects of nitrogen and phosphorus application method and nitrogen source on winter wheat grain yield and leaf tissue phosphorus. Soil Sci. Soc. Am. J. 47: 530-535.

LynGSTAD, I. 1977. Radgjødsling til korn. Forsøk i perioden 1966-75. Forskn. Förs. Landbr. 28: 159-177.

Macleod, L.B., Sterling, J.D.E. \& Macleod, J.A. 1975. Effects of rate, source and method of application of $\mathrm{N}, \mathrm{P}$ and $\mathrm{K}$ on growth, nutrient uptake and yield of barley. Can. J. Soil Sci. 55: 61-67.

Matiews-Roth, M.M. 1982. Antitumor activity of $\beta$ carotene, canthaxanthin and phytoene. Oncology 39 : 33-37.

Maynard, D.N., Barker, A.V., Minotti, P.L. \& Peck, N.H. 1976. Nitrate accumulation in vegetables. Adv. Agron. 28: 71-118.

Muford, G.F.J. 1973. The growth and development of the storage root of sugarbeet. Ann. Appl. Biol. 75: $427-438$.

Mulkey, J.R., Albach, E.L. Jr. \& Dainello, F.J. 1979. Response of onions to P placement. Agron. J. 71: 1037-1040.

Nicolaisen, W. \& HAAR, R. 1964. Untersuchungen über den Einflu $\beta$ einer Nitrat-Düngung auf den Gesamtstickstoff- und Nitrat-Gehalt von Möhren. Gartenb.wiss. 29: 463-480.

Nısson, T. 1979. Avkastning, lagringsförmåga, kvalitet och kemisk sammansättning hos morot, vitkål och purjo vid konventionell och organisk gödsling. Inst. Trädg. Vet. Rapp. 7: 3-52.

- 1987. Growth and chemical composition of carrots as influenced by the time of sowing and harvest. J. Agric. Sci. Camb, 108: 459-468.

Nygaard Sørensen, J. 1984. Dietary fibre and ascorbic acid in white cabbage as affected by fertilization. Acta Hort. 163: 221-230.

Pearson, C.H. \& Kırkham, M.B. 1980. Osmotic potential of wheat grown with fertilizer placed in strips or broadcasted. Fert. Res. 1: 227-234.

Pessi, Y., Ylánen, M., Leșkelà, A. \& Syvâl.ahtı, J. 1970. Results of tests made with placement fertilization on the Kotkaniemi experimental farm. J. Scient. Agric. Soc. Finl. 42: 193-202.

Peterson, G.A., Sander, D.H., Grabouski, P.H. \& HOOKER, M.L. 1981. A new look at row and broadcast phosphate recommendations for winter wheat. Agron. J. 73: 13-17.

Peto, R., Doll, R., Buckley, J.D. \& Sporn, M.B. 1981. Can dietary beta-carotene materially reduce human cancer rates? Nature 290: 201-208.

Phan, C.T. \& Hsu, H. 1973. Physical and chemical changes occurring in the carrot root during growth. Can. J. Pl. Sci. 53: 629-634.

Power, J.F., Grunes, D.L., Reichman, G.A. \& Willis, W.O. 1964. Soil temperature effects on $\mathrm{P}$ availability. Agron. J. 56: 545-548.

Randall, G.W., Wells, K.L. \& Hanway, J.J. 1985. Modern techniques in fertilizer application. In: "Fertilizer technology and use”. (Ed. O.P. Engelstad), p. $521-560$.

Robertson, J.A., Eastwood, M.A. \& Yedman, M.M. 1980. An investigation into the physical properties of fibre prepared from several carrot varieties at different stages of development. J. Sci. Food Agric. 31: $633-638$.

Salminen, K., Karinpā, A. \& Koivistoinen, P. 1970. Postharvest chemistry of carrots as such and modified by the preharvest use of herbicides chlorpropham (CIPC) and linuron. Acta Agric. Scand. 20: 49-57.

Salunke, D.K. \& Desal, B.B. 1984. Postharvest biotechnology of vegetables. II. 194 p. 1st Ed. Boca Raton, Florida.

Sangakmara, U.R. \& Cho, C.M. 1987. Effect of $\mathrm{NH}_{4}{ }^{+}$ nitrogen on phosphorus uptake by canola, lentils, soybeans and wheat. J. Agron. Crop Sci. 159: 199-201.

Schuphan, W. 1974. Experimental contributions to the problem of improving the nutritional quality of food plants. Qual. Plant. Pl. Foods Hum. Nutr. 24: 1-18.

Sımon, P.W., 1985. Carrot flavor: affects of genotype, growing conditions, storage and processing. In: "Evaluation of quality of fruits and vegetables". (Ed. H.E. Pattee), p. 315-328. Westport, Connecticut.

-, Peterson, C.E. \& Lindsay, R.C. 1982. Genotype, soil and climate effects on sensory and objective compo- 
nents of carrot flavor. J. Amer. Soc. Hort. Sci. 107: 644-648.

— \& WolfF, X.Y. 1987. Carotenes in typical and dark orange carrots. J. Agric. Food Chem. 35: 1017-1022.

Soon, Y.K. \& Miller, M.H. 1977. Changes in the rhizosphere due to $\mathrm{NH}_{4}{ }^{+}$and $\mathrm{NO}_{3}-$ fertilization and phosphorus uptake by corn seedlings (Zea mays L.). Soil Sci. Soc. Am. J. 41: 77-80.

Souci, S.W., Fachmann, W. \& Kraut, H. 1979. Die Zusammensetzung der Lebensmittel. Nährwert-Tabellen II: N-I,1. Stuttgart.

Southards, C.J. \& Miller, C.H. 1962. A greenhouse study on the macróelement nutrition of the carrot. Proc. Amer. Soc. Hort. Sci. 81: 335-340.

Spiller, G.A. \& Amen, R.J. 1975. Dietary fibre in human nutrition. Crit. Rev. Food Sci. Nutr. Nov. 39-70.

-, G.A. \& Freeman, H.J. 1981. Recent advances in dietary fiber and colorectal diseases. Am. J. Clinical Nutr. 34: 1145-1152.

Steel, R.G.D. \& Torrie, J.H. 1980. Principles and procedures of statistics. A biometrical approach. 633 p. 2nd Ed. Tokyo.

Steele, K.W. \& Saunders, W.M.H. 1980. Soil nitrification activity and phosphorus uptake by ryegrass after nitrogen fertilizer application. N.Z. J. Agric. Res. 23: $83-84$.

TERry, N. 1968. Developmental physiology of sugar beet. I. The influence of light and temperature on growth. J. Exp. Bot. 19: 795-811.

Timmons, D.R., Burwell, R.E. \& Holt, R.F. 1973. Nitrogen and phosphorus losses in surface runoff from agricultural land as influenced by placement of broadcast fertilizer. Water Resources Res. 9: $658-667$.

ULRICH, A. 1952. The influence of temperature and light factors on the growth and development of sugar beet in controlled climate environments. Agron. J. 44: 66-73.

- 1955. Influence of night temperature and nitrogen deficiency on the growth, sucrose accumulation and leaf minerals of sugar beet plants. Pl. Physiol. 30: 250-257.

VARIS, E. \& LANNETTA, I. 1974. Lannoitustavan vaikutus perunasadon kehittymiseen ja sadon laatuun. J. Scient. Agric. Soc. Finl. 46: 329-340. [Effects of fertilization rate and application method on the yield development and quality of potatoes.]

- 1975. Lannoitustavan vaikutus perunaravinteiden saantiin ja mukuloiden kemialliseen koostumukseen. J. Scient. Agric. Soc. Finl. 47: 1-13. [The effects of the fertilizer application method on the nutrient uptake of the potato and the chemical composition of the tubers.]

Varo, P., lähelmã, O., Nuurtamo, M., Saari, E. \& Koivistoinen, P. 1980. Mineral element composition of Finnish foods. VII. Potato, vegetables, fruits, berries, nuts and mushrooms. Acta Agric. Scand. 22: 89-113.

-, Laine, R., Veijalainen, K., Espo, A., Wetterhoff, A. \& Koivistoinen, P. 1984. Dietary fibre and available carbohydrates in Finnish vegetables and fruits. J. Agric. Sci. Finl. 56: 49-59.

Vulsteke, G. \& Biston, R. 1978. Factors affecting nitrate content in field-grown vegetables. Qual. Plant. Pl. Foods Hum. Nutr. 28: 71-87.

Vuorinen, M. \& TAKAla, M. 1987. Porkkanan ja punajuurikkaan sadetus, typpilannoitus ja kalkitus poutivalla hiekkamaalla. Maatalouden tutkimuskeskus. Tiedote 10: 1-30. [Irrigation, nitrogen fertilization and liming for carrot and redbeet on dry sandy soil. Communications of Agric. Res. Centre, Jokioinen.]

WiLlenbrinK, J. 1982. Storage of sugars in higher plants. In: "Plant carbohydrates I". (Eds. F.A. LoEwus and W. TANner), p. 691. Berlin.

Young, R.D., Westfall, D.G. \& Colliver, G.W. 1985. Production, marketing and use of phosphorus fertilizers. In: "Fertilizer technology and use". (Ed. O.P. Engelstad), p. 356.

Ms. received October 3, 1989 


\section{SELOSTUS}

\section{Lannoitusmenetelmien vaikutus porkkanan satoon ja sisäiseen laatuun}

\author{
Aino-Maija Evers \\ Kemira Oy, Espoon tutkimuskeskus \\ Luoteisrinne 2, 02270 Espoo
}

Kirjallisuustietojen mukaan lannoituksen hyötysuhteeseen, levitystasaisuuteen ja ympäristövaikutuksiin on mahdollista vaikuttaa kehittämällă lannoitteiden levitysmenetelmiä. Sen sijaan kirjallisuudessa on hyvin văhän tietoja siită, miten eri lannoitusmenetelmăt vaikuttavat vihannesten sisăiseen laatuun. Tämăn tutkimuksen tarkoitus oli selvittaaä, mihin porkkanan laadun kriteereihin lannoituksella ja lannoitusmenetelmillä voidaan vaikuttaa ja mitkä laadun kriteerit ovat niin voimakkaasti geneettisesti sảädeltyjä tai ilmastotekijöiden vaikutuksen alaisia, ettei niihin voida vaikuttaa lannoituksella tai lannoitusmenetelmillä.

Kenttăkokeet tehtiin Kotkaniemen koetilalla Vihdissä kasvukausina 1985 ja 1986. Koekentăn maalaji on erittăin runsasmultainen, savinen hieno hieta. Viljelty lajike oli Nantes Duke Notabene 370 Sv. Vertailtavina lannoitusmenetelmină olivat sijoitus- ja pintalannoitus (ilman kastelua ja kastelun kera), NPK-kastelulannoitus, jossa puolet ravinteista annettiin sijoituslannoituksena keväällä, sekă menetelmăt, joissa $\mathrm{P}$ ja $\mathrm{K}$ annettiin sijoittaen kevaaăllă ja N kastelulannoituksena kasvukaudella jaksottaen (kaksi $\mathrm{N}$-lannoitustasoa).

Vuonna 1985 porkkanan juuri- ja naattinăytteet kerăttiin kolme kertaa kasvukauden aikana tuore- ja kuivapainomäärityksiin sekä $\mathrm{NO}_{3}-\mathrm{N}-, \mathrm{N}-, \mathrm{P}-, \mathrm{K}-, \mathrm{Ca}-$ ja $\mathrm{Mg}$ mảarityksiin. Juurinäytteet kerăttiin sadonkorjuun yhteydessă sadon punnitusta varten ja karoteeni-, glukoosi-, fruktoosi- ja sakkaroosimaaărityksiin sekả aistinvaraiseen arviointiin. Kuuden kuukauden varastoinnin jălkeen kauppakelpoinen sato punnittiin ja painohäviö merkittiin muistiin, karoteenipitoisuus mäăritettiin ja maku ja rakenne arvioitiin aistinvaraisella menetelmăllä.

Vuonna 1986 porkkanan juuri- ja naattinäytteet kerăttiin kolme kertaa kasvukauden aikana tuore-, kuivapainoja $\mathrm{NO}_{3}-\mathrm{N}$-määrityksiin, ja juurinäytteet karoteenimäärityksiin. Juuri- ja naattinäytteet kerăttiin sadonkorjuun yhteydessä N-, P-, K-, Ca-, Mg- ja tuhkamäärityksiin ja juurinăytteet sato-, ravintokuitu-, glukoosi-, fruktoosija sakkaroosimaaărityksiin sekä aistinvaraiseen maun ja rakenteen arviointiin. Neljăn kuukauden varastoinnin jälkeen kauppakelpoinen sato punnittiin ja painohäviö merkittiin muistiin, karoteeni, $\mathrm{NO}_{3}-\mathrm{N}, \mathrm{N}, \mathrm{P}, \mathrm{K}, \mathrm{Ca}, \mathrm{Mg}$, tuhka, glukoosi, fruktoosi ja sakkaroosi määritettiin ja aistinvaraisella arvioinnilla tutkittiin maku ja rakenne.

Vuonna 1986 kerättiin näytemateriaalia kahdelta orgaanisesti viljellyltå pellolta, jotta saataisiin havaintoaineistoa myös orgaanisesti kompostilla lannoitetuista porkkanoista. Năită tuloksia ei verrattu tilastollisesti lannoituskokeen tuloksiin.

Porkkanan juurien ja naattien kuivapainot korreloivat positiivisesti kaikkina näytteenottoaikoina molempina vuosina. Suuri yhteyttãvă naatisto tuotti suuren juurisadon. Sijoituslannoitus lisãsi satoa verrattuna pintalannoitukseen. Sato oli suurempi menetelmässä, jossa $\mathrm{P}$ ja $\mathrm{K}$ annettiin sijoituslannoituksena kuin menetelmissä, joissa $\mathrm{P}$ ja $\mathrm{K}$ annettiin pinta- tai kastelulannoituksena. Sadossa ei ollut eroa, annettiinpa ravinteet yhdellä kerralla tai jaksoittain.

Lannoittamattomien ja lannoitettujen porkkanoiden kuiva-ainepitoisuudessa ei ollut eroja sadonkorjuuvaiheessa. Kuiva-ainepitoisuuden erot olivat suuremmat eri vuosien vălillä kuin eri lannoitustapojen vălillă. Kuivaainepitoisuus oli suurempi niissă porkkanoissa, joille $\mathrm{P}$ ja $\mathrm{K}$ annettiin sijoituslannoituksena ja $\mathrm{N}$ kastelulannoituksena kuin niissä porkkanoissa, joille kaikki ravinteet annettiin NPK-kastelulannoituksena.

Porkkanan karoteenipitoisuus on geneettisesti säädelty ominaisuus, ja saaătila ja kasvin ikă vaikuttavat siihen suuresti. Lannoitusmenetelmillă oli vaikutusta porkkanan karoteenipitoisuuteen vain sảäoloiltaan epäedullisena vuonna 1985. Tällöin porkkanoissa, jotka olivat saaneet fosforia ja kaliumia sijoituslannoituksena ja typpeä kastelulannoituksena kasvukaudella, oli suuntaa antavasti ( $\mathrm{p} \leq 0.1)$ korkeampi karoteenipitoisuus kuin niissä porkkanoissa, jotka oli pintalannoitettu, joita oli kasteltu ja jotka saivat lannoitetta kerran keväăllă tai jotka oli NPKkastelulannoitettu. Karoteenipitoisuudet olivat myös suuntaa antavasti korkeammat niissä porkkanoissa, jotka sai- 
vat $\mathrm{P}: \mathrm{n}$ ja K:n sijoituslannoituksena kuin niissä porkkanoissa, joille $\mathrm{P}$ ja $\mathrm{K}$ annettiin pinta- tai kastelulannoituksena.

Lannoitusmenetelmillä oli vaikutusta porkkanan juurien $\mathrm{NO}_{3}-\mathrm{N}$-pitoisuuteen. $\mathrm{NO}_{3}-\mathrm{N}$-pitoisuus oli korkeampi NPK-kastelulannoituksen saaneissa porkkanoissa kuin niissä porkkanoissa, joille $\mathrm{P}$ ja $\mathrm{K}$ annettiin peruslannoituksena sijoittaen ja $\mathrm{N}$ kastelulannoituksena kasvukaudella, tai porkkanoissa, joille kaikki ravinteet annettiin kerralla keväällä joko sijoittaen tai pintalannoituksena. Kastelu nosti $\mathrm{NO}_{3}$-N-pitoisuutta.

Lannoitusmenetelmillă oli vaikutusta porkkanoiden $\mathrm{N}$-, P-, tuhka- ja ravintokuitupitoisuuksiin, mutta niillă ei ollut vaikutusta $\mathrm{K}$-, Ca-, Mg-, glukoosi-, fruktoosi- tai sakkaroosipitoisuuksiin. Tutkimuksessa on esitetty hypoteesi, ettă porkkanan sokeripitoisuuksia pitäisi tarkastella suhteessa kasvuun. Tilanteissa, joissa kasvu on voimakasta, kasvi käyttaaă huomattavan osan yhteyttämistuotteista eli sokereista uuden kasvimassan tuottamiseen. Tilanteissa, joissa jokin kasvutekijä rajoittaa kasvua, yhteyttämistuotteita eli sokereita jaă "yli" ja niitä kertyy kasviin.

Aistinvaraisesti arvioidut makuerot eri lannoitustapojen vălillä olivat pienet. Kumpanakin vaonna NPKkastelulannoituksen saaneiden porkkanoiden maku oli parempi kuin sijoituslannoituksen saaneiden porkkanoiden maku. Sijoituslannoituksen ja kastelun saaneiden porkkanoiden maku oli parempi kuin ilman kastelua viljeltyjen sijoituslannoituksen saaneiden porkkanoiden maku. Lannoitusmenetelmillă oli vain văhäisiă vaikutuksia varastoidun porkkanan laatuun. NPK-kastelulannoitus heikensi suuntaa antavasti porkkanan varastokestävyyttä.

Sadonkorjuuvaiheessa orgaanisesti viljeltyjen porkka- noiden sato oli pienempi, N-pitoisuus alhaisempi ja maku huonompi, mutta P- ja Mg-pitoisuudet korkeammat kuin lannoitettujen porkkanoiden keskimääräiset vastaavat arvot lannoituskokeessa. Varastoinnin jälkeen orgaanisesti viljeltyjen porkkananäytteiden kauppakelpoinen sato oli suurempi, painohäviö pienempi, $\mathrm{NO}_{3}-\mathrm{N}$-pitoisuus alhaisempi, P-, Mg-, glukoosi- ja fruktoosipitoisuudet korkeammat ja maku ja rakenne paremmat, mutta kuiva-ainepitoisuus ja $\mathrm{N}$ - ja Ca-pitoisuudet olivat alhaisemmat kuin lannoitettujen porkkanoiden vastaavat arvot keskimaaărin lannoituskokeessa. Orgaanisesti viljeltyjen porkkanoiden parempaan varastokestävyyteen vaikutti se, ettei maalevintäinen mustamätä heikentănyt niiden laatua, kuten tapahtui lannoituskokeen porkkanoille.

Yhteenvetona voidaan todeta, että lannoitusmenetelmillă oli vaikutusta porkkanan satoon, kuiva-aine-, $\mathrm{NO}_{3}-\mathrm{N}-, \mathrm{N}-$, P-, tuhka- ja ravintokuitupitoisuuksiin. Toisaalta lannoitusmenetelmillă ei ollut vaikutusta tai oli vain vähäinen vaikutus karoteeni- ja sokeripitoisuuksiin, makuun, rakenteeseen ja varastoidun porkkanan laatuun. NPK- tai PK-lannoitteiden antaminen sijoituslannoitustekniikalla vaikutti myönteisesti satoon sekä kuiva-aine-, $\mathrm{NO}_{3}-\mathrm{N}$-, N- ja P-pitoisuuksiin verrattuna NPK-kastelulannoitukseen. Yksi levityskerta vaikutti myönteisesti tuhka- ja ravintokuitupitoisuuksiin. Karoteeni- ja sokeripitoisuudet, samoin kuin varastokestävyys, ovat niin voimakkaasti geneettisesti sảädeltyjä, ettei lannoitusmenetelmillă ole niihin merkittăväă vaikutusta. Sen sijaan kasvukauden sääolot vaikuttavat niihin paljon. Tekijöistä, jotka vaikuttavat porkkanan makuun, tiedetään toistaiseksi vähän. 